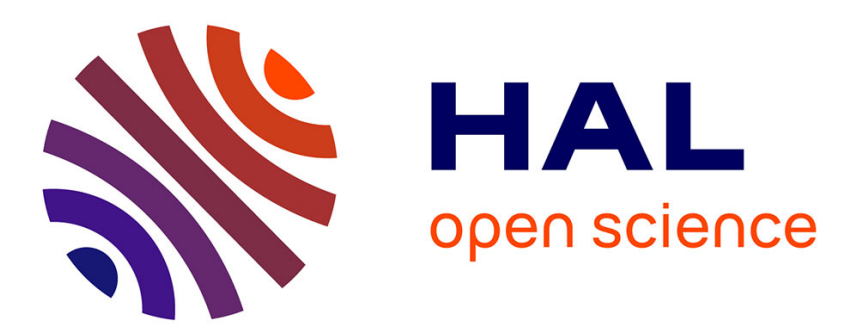

\title{
Environmental carcinogenesis and pH homeostasis: Not only a matter of dysregulated metabolism
}

Kévin Hardonniere, Laurence Huc, Odile Sergent, Jørn A Holme, Dominique Lagadic-Gossmann

\section{To cite this version:}

Kévin Hardonniere, Laurence Huc, Odile Sergent, Jørn A Holme, Dominique Lagadic-Gossmann. Environmental carcinogenesis and $\mathrm{pH}$ homeostasis: Not only a matter of dysregulated metabolism. Seminars in Cancer Biology, 2017, 43, pp.49-65. 10.1016/j.semcancer.2017.01.001 . hal-01531077

\section{HAL Id: hal-01531077 https://hal-univ-rennes1.archives-ouvertes.fr/hal-01531077}

Submitted on 1 Jun 2017

HAL is a multi-disciplinary open access archive for the deposit and dissemination of scientific research documents, whether they are published or not. The documents may come from teaching and research institutions in France or abroad, or from public or private research centers.
L'archive ouverte pluridisciplinaire HAL, est destinée au dépôt et à la diffusion de documents scientifiques de niveau recherche, publiés ou non, émanant des établissements d'enseignement et de recherche français ou étrangers, des laboratoires publics ou privés. 


\section{Environmental carcinogenesis and $\mathrm{pH}$ homeostasis: not only a matter of dysregulated metabolism}

By

Kévin HARDONNIERE ${ }^{1,2}$, Laurence HUC ${ }^{3}$, Odile SERGENT ${ }^{1,2}$, Jørn A. HOLME ${ }^{4}$, and Dominique LAGADIC-GOSSMANN ${ }^{1,2 *}$

${ }^{1}$ Institut national de la santé et de la recherche médicale (Inserm), Institut de recherche en santé, environnement et travail (Irset - Inserm UMR 1085), F-35043 Rennes, France

${ }^{2}$ Université de Rennes 1, Structure fédérative de recherche Biosit, UMS CNRS 3480/US Inserm 018, F 35043 Rennes, France

3INRA UMR 1331 ToxAlim (Research Center in Food Toxicology), University of Toulouse ENVT, INP, UPS, 180 Chemin de Tournefeuille, F-31027, France

${ }^{4}$ Domain of Infection Control, Environment and Health, Norwegian Institute of Public Health, Oslo, Norway

To whom correspondence should be addressed:

Dr. Dominique Lagadic-Gossmann, Inserm U1085 / IRSET, Université Rennes 1,

Faculté de Pharmacie, 2 avenue du Professeur Léon Bernard, 35043 Rennes cedex, France;

Tel: +33(0)223234837;

Fax: +33(0)2 23235055

E-mail: dominique.lagadic@univ-rennes1.fr 


\section{Abstract}

According to the World Health Organization, around $20 \%$ of all cancers would be due to environmental factors. Among these factors, several chemicals are indeed well recognized carcinogens. The widespread contaminant benzo[a]pyrene (B[a]P), an often used model carcinogen of the polycyclic aromatic hydrocarbons' family, has been suggested to target most, if not all, cancer hallmarks described by Hanahan and Weinberg. It is classified as a group I carcinogen by the International Agency for Research on Cancer; however, the precise intracellular mechanisms underlying its carcinogenic properties remain yet to be thoroughly defined. Recently, the pH homeostasis, a well known regulator of carcinogenic processes, was suggested to be a key actor in both cell death and Warburg-like metabolic reprogramming induced upon $\mathrm{B}[\mathrm{a}] \mathrm{P}$ exposure. The present review will highlight those data with the aim of favoring research on the role of $\mathrm{H}^{+}$dynamics in environmental carcinogenesis.

Abbreviations: AhR: aryl hydrocarbon receptor; B[a]P: benzo[a]pyrene; CYP: cytochrome P450; EMT: epithelial-to-mesenchymal transition; $\mathrm{Cx} 43$ : connexin 43; GJIC: gap junction intercellular communication; HMGCoA reductase: 3-hydroxy-3-methylglutaryl-CoA reductase; $\mathrm{NHE1}: \mathrm{Na}^{+} / \mathrm{H}^{+}$ exchanger; $\mathrm{PAH}$ : polycyclic aromatic hydrocarbon; $\mathrm{pH}_{\mathrm{i}}$ : intracellular $\mathrm{pH} ; \mathrm{pH}_{\mathrm{e}}$ : extracellular $\mathrm{pH}$; $\mathrm{TCA}$ cycle: tricarboxylic acid cycle; TCDD: 2,3,7,8-tetrachlorodibenzo-p-dioxin; $\Delta \psi \mathrm{m}$ : mitochondrial membrane potential; $\Delta \mathrm{p}$ : proton motive force; $\Delta \mathrm{pHm}$ : cytosol-mitochondrial proton gradient.

Key words: $\mathrm{pH}$ and carcinogenesis; benzo[a]pyrene; $\mathrm{Na}+\mathrm{H}+$ exchanger; apoptosis; Warburg effect

\section{Introduction}

An increased human lifespan along with the improvement of screening and diagnostic methods cannot alone explain the increasing incidence of certain types of cancers. Several studies 
have pointed out that factors related to the so-called western lifestyle such as a high-fat diet, alcohol consumption and cigarette smoking, represent important risk factors with regard to the development of several of these cancers. Some occupational activities are also responsible for cancer development; in line with this, it is worth noting that the chimney sweepers' cancer, also called "soot wart", has been the first reported form of occupational cancer; this cancer targets the skin of scrotum, and was initially identified by Percivall Pott in 1773 [1]. As a result of this knowledge and following restriction campaigns, smoking and for some countries also alcohol consumption have been declining for several years, thus leading to a decrease in the number of aero-digestive tract and esophageal cancers. Regulations have also been set up to limit or prevent the chemical exposure of workers. However, the incidence of several other cancers including hepatocellular carcinoma (HCC) (European Cancer Observatory, http://eu-cancer.iarc.fr) is still increasing. Important risk factors notably for development of $\mathrm{HCC}$, in addition to those mentioned above, include infections like Hepatitis $C$ and $B$ viruses, and natural compounds like the mycotoxin aflatoxin B1 [2].

During the last decades, intensive chemical testing and regulations have most probably reduced the likelihood of being exposed to complete genotoxic chemical carcinogens. However, spontaneous DNA damage occurs in all tissues at a high frequency, and various types of genetically predispositions exist. As cancer is due to a combined action of several factors, there is a growing awareness that chemically-induced DNA damage may not always be the limiting factor for cancer development. Furthermore, we are still exposed to an increasing amount of chemicals for which the combined actions are often unknown. Thus, this type of involuntary exposure could contribute to the increasing incidence of different types of cancers in industrialized countries. Indeed, according to data obtained through the World Health Organization, approximately $20 \%$ of cancer deaths would be due to environmental factors [3].

The complete elimination of environmental chemicals, either synthetic or natural, which contribute to the carcinogenic processes, is technically unfeasible. In this context, human exposure 
to toxic chemicals is therefore inevitable, particularly due to food contamination and air pollution. Important combined factors associated with lifestyle are well identified and accessible to epidemiological studies using traditional epidemiological methods. This is not the case for examination of the effects of low doses of individual chemicals that may differentially be involved in the carcinogenic process. Furthermore, as stated above, the combined effects of environmental chemicals due to their diversity and widespread distribution may potentially make an important contribution to the overall process of cancer development. Hence, as recently stressed by the Halifax project consortium [4, 5], there is an urgent need to develop studies on the biological and toxicological effects of these contaminants to increase our knowledge about their action mechanisms, notably with regard to carcinogenesis.

The precise sequencing of the carcinogenic process is still not fully elucidated, and in a recent comprehensive review, the process was suggested to include tumor initiation, tumor formation and progression, matrix remodeling, intravasation, extravasation and metastasis [4]. Important acquisition hallmarks are genetic instability, tumor-promoting inflammation, sustained proliferative signaling, insensitivity to antigrowth signals, replicative immortality, dysregulated metabolism, resistance to cell death, angiogenesis, tissue invasion and metastasis [6]. One key parameter for the occurrence of several of these cancer hallmarks is intracellular $\mathrm{pH}\left(\mathrm{pH}_{\mathrm{i}}\right)$ [7-12]. Based upon the fact that alterations in cell $\mathrm{H}^{+}$homeostasis could also result from exposure to environmental carcinogens, it is important to review the role of these alterations in the occurrence of some of the cancer hallmarks in order to bring some new clues to the understanding of environmentally-linked cancer development. This review will mainly focus on the impact of $\mathrm{pH}$ homeostasis in polycyclic aromatic hydrocarbons (PAHs)-induced effects on resistance to cell death and dysregulated metabolism/cellular energetics. Indeed the PAHs are among the molecules worth considering when focusing on the etiology of diverse cancers since they are widespread in our environment and 
constitute the largest class of environmental carcinogens. However, when necessary, reference to other environmental carcinogens will also be made.

\section{Generalities on the PAH family}

\subsection{Sources and exposure}

PAHs are major environmental pollutants which are primarily formed during incomplete combustion or pyrolysis of organic material such as gasoline, diesel fuel, coal, oil, food (grilled, barbecued or smoked) and tobacco. These substances are therefore found in polluted air, water, soil and food. In the air, they are often bound to particulate matter (PM). PAHs constitute a large class of organic compounds that are composed of at least two fused aromatic rings. They generally occur in complex mixtures which can contain several of them. This family exhibits a large diversity of chemical structure, with more than 500 different molecules detected in our environment [13]. As humans are exposed to PAHs by various routes (inhalation, dermal and oral routes), the target organs will depend on the exposure route. Thus, following an in vivo oral exposure of rodents, benzo[a]pyrene (B[a]P) which is the prototype molecule of PAHs, was reported as leading to tumors of larynx, esophagus, stomach, colon and liver [14-16], while inhalation would mainly result in lung tumors [17].

For non-smokers the major route of exposure is via food consumption, whereas for smokers the contribution from smoking can be significant. Food can be contaminated from environmental sources, industrial food processing and from certain home cooking practices. Diverse studies have shown that for non-occupationally exposed, non-smokers individuals, over $70 \%$ of exposure to PAHs arises from the diet, with cereals being the predominant source $[13,18,19]$. Thus, it has been estimated that the median dietary intake of $3 \mu \mathrm{g} /$ day for total PAHs represents around $96 \%$ of the total daily exposure of non-smokers in general population; this intake can reach up to $15 \mu \mathrm{g} / \mathrm{day}$ 
depending on diet, and for smokers, the dose might be twice that of non-smokers [20]. Regarding $\mathrm{B}[\mathrm{a}] \mathrm{P}$, the median daily intake has been estimated in the range of $0.040-0.180 \mu \mathrm{g} / \mathrm{day}[18]$. The rate of PAH absorption by the organism depends on diverse physicochemical characteristics [21, 22]; e.g. for lung, this rate will depend on PAH lipophilicity and the type and size of the PM they are adsorbed onto [23].

\subsection{Toxicity and action mechanisms}

PAHs can exert various deleterious effects, resulting for example in teratogenesis, immunesuppression or cancer development (see e.g. reviews [24-26]). With respect to cancer, many of these contaminants have been defined as carcinogens. Thus, among the $16^{\text {th }}$ PAHs recognized as toxic substances by the US Environmental Protection Agency (US EPA), one can cite B[a]P, dibenzo[a,h]anthracene, benzo[b]fluoranthene, indenol[1,2,3-c,d]pyrene; others, such as phenanthrene or pyrene, would not be carcinogenic [24]. The toxicity of PAHs greatly differs from one another, notably depending on their structure and their metabolism by cytochromes P450 (CYPs).

\section{Binding and activation of the aryl hydrocarbon receptor}

Several PAHs, including $\mathrm{B}[\mathrm{a}] \mathrm{P}$, can bind and activate a low-molecular-weight cytosolic receptor called the aryl hydrocarbon receptor (AhR). The mechanisms involved in AhR activation will not be discussed here since these have been the topics of recent reviews (see e.g. [27, 28]). However, it is worth stressing that the expression of this receptor is increased in several types of cancer such as hepatocellular carcinoma or aero-digestive cancers [29-31]. In addition, AhR has been shown to be essential for the PAH-induced genotoxic and carcinogenic in vivo responses [32]. Ligand-activated AhR complexes can interact with specific promoter elements called aromatic hydrocarbon response

elements (AHRE; also called XRE [xenobiotic-responsive element] or DRE [dioxin-responsive elements]), which are present in the $5^{\prime}$-region of a subset of cellular genes including the cytochromes 
P450s CYP1A1, CYP1A2 and CYP1B1. In this way, PAHs promote their own metabolism [33, 34]. It is worth noting that AhR has also been found to activate non-genomic pathways, notably in link to plasma membrane $[35,36]$ and/or to mitochondrial location [37, 38].

\section{Formation and binding of reactive metabolites}

In general, most of the parent compounds are detoxified. However, PAH metabolism can be harmful to cells, through the production of highly reactive electrophilic metabolites as well as reactive oxygen species (ROS) which then damage cellular macromolecules such as DNA, lipids or proteins [3943]. The diol-epoxide metabolites are considered to be the most mutagenic and tumorigenic, notably through the formation of DNA-adducts [44-46]. In addition, the related ROS production may also lead to DNA damage $[47,48]$, through the formation of 8-oxo-7,8-dihydro-2'-deoxyguanosine (8-oxodG) $[39,41,43]$. Both types of DNA damages, if not repaired, may then lead to important consequences in terms of DNA mutations [43-46], or to activation of cell death processes [49].

\section{Cellular responses/signaling pathways}

The checkpoint pathways to remove the DNA damages involve different proteins that act together to translate the signal of damaged DNA into cell response towards cycle arrest, DNA-repair, survival or cell death. These responses are very complex since multiple synchronous signals are initiated [50]. The final result would also depend on the concentration of the genotoxic agent, the exposure time and the resulting biological milieu including the cell redox state, $\mathrm{pH}$, calcium concentration, and ATP level, as well as the occurrence of extracellular signals.

Regarding $\mathrm{pH}$, it is noteworthy that decreasing extracellular $\mathrm{pH}$ increases the frequency of chemically-induced morphological transformation of Syrian Hamster Embryo cells [51], notably upon $\mathrm{B}$ [a]P exposure [52]. In addition, such an extracellular acidification might impair the biotransformation of carcinogens in favor of bioactivation. Indeed a decrease in the activity of glutathione-S-transferases, which allow the clearance of PAHs [17, 53], has been observed upon decreasing extracellular pH [54]. 
This might be due to an impact of acidic $\mathrm{pH}$ on the intracellular glutathione level [55]. Besides, intracellular acidification per se might be involved in DNA damage, as previously shown upon exposure to bile acids of HET1A cells, a cell line derived from normal human oesophagus [56]. In this context, pH appears as an important parameter to focus on when investigating the mode of action of environmental carcinogens.

Most of the literature reporting the carcinogenic effects of PAHs deal with $\mathrm{B}[\mathrm{a}] \mathrm{P}$ which serves as a reference for the carcinogenicity of other PAHs [57]. We will therefore focus on the intracellular mechanisms underlying the carcinogenicity of this pollutant in the following sections of our review, with a special attention regarding the role of $\mathrm{H}^{+}$dynamics.

\section{Benzo[a]pyrene: a complete environmental carcinogen}

$\mathrm{B}[\mathrm{a}] \mathrm{P}$, notably present in cigarette smoke, diesel exhaust particles, grilled food, is a highly lipophilic compound which is metabolized in particular in the liver by the CYP1 family. Some of the produced metabolites are highly reactive and can then form DNA adducts with a high mutagenic potential. Based upon this type of action mechanism, combined with in vivo animal as well as epidemiological studies, this compound has been classified as a genotoxic carcinogen to humans (class I carcinogen) by the International Agency for Research on Cancer [58]. Classically, carcinogenesis has been described as a multi-step process, with firstly the "initiation" of a single cell, caused by irreversible genetic changes, leading to mutations of genes notably related to control of growth and/or apoptosis. The second step is "promotion" that is often caused by proliferation of initiated cells which have become resistant to apoptosis and lost the ability to differentiate. The proliferation of these initiated cells might also be favoured by the induction of apoptosis in normal cells, through activation of compensatory proliferative processes. This leads to a situation 
("progression" step) whereby additional genetic and epigenetic events can take place to confer the necessary phenotypes of invasiveness and metastasis. Besides, angiogenesis also plays an essential role in this carcinogenic process $[59,60] . \mathrm{B}[\mathrm{a}] \mathrm{P}$ has been described as a complete carcinogen, with recognized effects on the different steps of the carcinogenic process, as detailed below.

\subsection{Initiation step (reactive molecules and DNA damage)}

It has long been known that, following metabolism of $\mathrm{B}[\mathrm{a}] \mathrm{P}$, several reactive metabolites are produced, among which the electrophilic B[a]P-metabolite $r-7, t-8$-dihydrodiol-t-9,10-oxy-7,8,9,10tetrahydrobenzo[a]pyrene (BPDE) $[33,53]$. This metabolite reacts with DNA to generate large, bulky DNA adducts, primarily deoxyguanoside-BPDE. These stable BPDE- $\mathrm{N}^{2}$-dG DNA-adducts have thus been found in tissues of exposed experimental animals as well as in humans, notably in lung, blood and liver [61-64], and have been related to cancers [65]. Interestingly, these DNA adducts are formed at several TP53 CpG mutation hotspot sites (in codons 157, 248 and 273), similarly to the major mutational hotspots evidenced in human cancers [66-69]. In parallel to the p53 tumor suppressor gene, the K-ras proto-oncogene is also targeted by BPDE and frequently mutated in smoking-induced lung cancer [70].

BPDE has further been shown to induce several times more mitochondrial DNA (mtDNA) damage compared to nuclear DNA damage [71]. A possible explanation, though not yet investigated, might be the presence in mitochondria of the CYPs (e.g. CYP1B1) involved in B[a]P bioactivation [72]. Another explanation might be the lack of mtDNA nucleotide excision repair [73]. Interestingly, a very recent study indicates that such BPDE-related mtDNA damage would not lead to mtDNA mutations, these latter being more dependent on ROS [74].

Besides the CYP/epoxide hydrolase (EH)-catalysed pathway leading to BPDE production, $\mathrm{B}[\mathrm{a}] \mathrm{P}$ metabolism also relies on two other pathways: the B[a]P o-quinone pathway (catalysed by the aldo ketose reductase (AKR), following synthesis of ( \pm )-B[a]P-trans-7,8-dihydrodiol [B[a]P-7,8-DHD]), 
and the $\mathrm{B}[\mathrm{a}] \mathrm{P}$ radical cation pathway (catalyzed by the $\mathrm{P} 450$ peroxidase)[75]. In this context, $\mathrm{B}[\mathrm{a}] \mathrm{P}$ exposure can lead to the formation of DNA adducts via the production of different metabolites [76]. However, the resulting cellular consequences of these different DNA adducts appear to differ. Accordingly, DNA adducts formed by $\mathrm{B}[\mathrm{a}] \mathrm{P}$ radical cations would not be related to known cancer hotspots [77]. With regard to the o-quinone pathway, transformation of $\mathrm{B}[\mathrm{a}] \mathrm{P}-7,8-\mathrm{DHD}$ by dihydrodiol dehydrogenase, leads to production of catechols. These molecules may then undergo one electron redox cycling forming semiquinone radicals and quinones. In addition to be DNAreactive themselves, they may thus result in the formation of ROS including superoxide anion $\left(\mathrm{O}_{2}{ }^{-}\right)$, hydroxyl radical $(\mathrm{OH})$ and hydrogen peroxide $\left(\mathrm{H}_{2} \mathrm{O}_{2}\right)$ [78], notably in cell nucleus [77]. These reactive species can then lead to DNA damage with consequences in terms of mutations by misreplication or misrepair of the DNA damage. In line with this, it has for example been shown that mice exposed to $\mathrm{B}[\mathrm{a}] \mathrm{P}$ exhibit increased levels of 8-OHdG in lung [79]; a similar increase can also be found in other cells/tissues such as lymphocytes, liver and/or stomach [80-82].

\subsection{Promotion phase: cellular signaling pathways}

\section{Pro- and anti-apoptotic signals}

The relative proportion of the different cell signaling pathways triggered by the DNA damage of carcinogens will to a large degree determine their potential mutagenic and carcinogenic effects. If the cells survive with more DNA damage due to pro-survival/anti-apoptotic signals, the probability of having a mutation may increase. Following B[a]P-triggered DNA damage, diverse signaling pathways activate p53 [83], thereby leading to cell cycle arrest and cell death when DNA damage is not repaired [84-88]. However, B[a]P has also been suggested to activate p53-independent cell death processes [89], notably involving modulation of the Bcl-2 family members, with an upregulation or downregulation of the expression of anti-apoptotic (eg. Bcl-2) or pro-apoptotic proteins (eg. Bax and Bak), respectively [90, 91]. Furthermore, our group has previously demonstrated a role for a non-genotoxic pathway which 
relies on the $\mathrm{Na}^{+} / \mathrm{H}^{+}$exchanger 1 (NHE1), and works together with the p53 pathway to speed up the cell death onset in hepatic cells $[92,93]$; this will be further detailed in section 4.

Different types of cell death have been described upon B[a]P exposure, with the occurrence of apoptosis [85-88] as well as necrosis/necroptosis [90, 91, 94, 95]. Regarding the B[a]P-induced apoptosis, the intrinsic mitochondrial pathway has been the most often reported, with an activation of effector caspases $3 / 7$, associated or not with a release of cytochrome c $[86,96-98]$. The associated mitochondrial dysfunction can in this case result from changes in expression and/or intracellular location of different Bcl-2 family members [84, 85, 88]. Translocation of hexokinase II (HKII) from mitochondria to cytosol might also be involved in this dysfunction, depending on both NHE1 and p53 pathways [93,99].

Though far less studied, the extrinsic apoptotic pathway might also be activated upon B[a]P exposure, notably through the modulation of the expression of the death receptor Fas/CD95 $[88,100]$. Besides, $\mathrm{B}[\mathrm{a}] \mathrm{P}$ has been found to sensitize human keratinocytes for the apoptosis induced by the Fas ligand or the cytokine TRAIL via an AhR-dependent potentiation of caspase-8 activity [101]. With respect to the $\mathrm{B}[\mathrm{a}] \mathrm{P}$-induced necrosis/necroptosis, in addition to a possible involvement of some Bcl-2 family members [90, 91], it has been shown that ROS production and lipid peroxidation [95] as well as PARP-1, an enzyme involved in DNA repair [94], would also play a role. Regarding PARP-1, the work by Lin \& Yang [94] shows that the formation of DNA adducts upon B[a]P exposure activates this enzyme, thereby decreasing the $\mathrm{NAD}^{+}$level, which is essential for cell energy production.

\section{Mitochondrial damage/dysfunction}

There are several studies that point to possible mechanisms linking B[a]P exposure to cell energy defects. Thus, $\mathrm{B}[\mathrm{a}] \mathrm{P}$ has been shown to hamper the oxidative phosphorylation (OXPHOS) of lung mitochondria in vivo. A decrease in the activities of the mitochondrial complexes I to IV as well as of several enzymes of the tricarboxylic acid cycle (TCA) , was further demonstrated under those conditions [79], which may explain the observed decrease in ATP synthesis. In contrast, other studies rather suggest 
an increase in OXPHOS as measured in mitochondria isolated from B[a]P-treated rat liver [102]. These apparent divergent results might be due to differences in the experimental setup. In line with this, Salazar et al. [102] found that the increased cell respiration occurring early following animal exposure to $\mathrm{B}[\mathrm{a}] \mathrm{P}$ gradually declined. The increase in cell respiration might be envisioned as an early protective response developed by the cell against $\mathrm{B}[\mathrm{a}] \mathrm{P}$ toxicity.

$\mathrm{B}[\mathrm{a}] \mathrm{P}$-induced mitochondrial dysfunction may also lead to ROS production, which might be due to CYP-dependent metabolism within this organelle [72]. The mitochondrial ROS production often results in necrosis [95], but may also be a part of the apoptotic process. Indeed, using several antioxidant molecules, B[a]P-induced cell apoptotic death was found to be counteracted in the F258 rat hepatic epithelial cell line $[92,93]$. Furthermore, the use of two different specific iron chelators which reduce oxidative stress by hampering the Fenton reaction, suggested that this process could participate in the $\mathrm{B}[\mathrm{a}] \mathrm{P}$-induced apoptosis [103]. Furthermore, there seems to be a dialogue between mitochondria and Iysosomes. Indeed, both a membrane permeabilization and an alkalinization of lysosomes were detected in B[a]P-treated F258 cells, thereby leading to the release of the lysosomal protease lactoferrin which then activated the effector caspase 3 [104]. Such a lysosome permeabilization might result from ROS, as shown in primary cultures of rat hepatocytes upon $\mathrm{B}[\mathrm{a}] \mathrm{P} / \mathrm{ethanol}$ co-exposure [105]. Besides a caspasedependent apoptotic pathway, $\mathrm{B}[\mathrm{a}] \mathrm{P}$ has also been proposed to trigger a caspase-independent pathway depending on activation of the endonuclease LEI/L-DNase II [86]. Such an activation would be favored by the intracellular acidification resulting from the B[a]P-induced mitochondrial dysfunction [86, 92].

\section{Proliferative and survival stimuli}

As also discussed above, it appears that B[a]P-exposed cells switch between multiple signaling pathways during cell death, partly depending on time and/or dose. Cell death processes triggered by 
environmental carcinogens like B[a]P may on one hand protect tissues by removing cells having extensive DNA damage. However, cell death caused by genotoxic carcinogens may on the other hand initiate mitotic signals to the surrounding cells with less DNA-damage, thus increasing their probability of having mutations. In the long run, carcinogen-induced cell death may promote growth of cells with genetic and/or epigenetic changes which give them growth advantages. Often such cells are found to be more resistant towards cell death. This process which leads to a selection of more aggressive cancer cells, is regarded as an important part of neoplastic promotion and progression. The role of apoptosis as an oncogenic process has been very recently reviewed [106], and will not be further detailed here.

Several survival signals can be triggered by $\mathrm{B}[\mathrm{a}] \mathrm{P}$ along with an impairment of cell death pathways, notably through targeting of the pro-apoptotic members of the Bcl-2 family. Thus, inactivation by phosphorylation of the pro-apoptotic protein Bad, likely resulting from activation of the survival-related protein kinase Akt, has been detected in B[a]P-treated Hepa1c1c7 hepatoma cells at early time points [84]. Burdick and collaborators [107] showed that Akt can be activated via a calcium/Pyk2/Epidermal Growth Factor receptor (EGFR) pathway in BPDE-treated human mammary epithelial cell line MCF-10A. Furthermore, they found that inhibitors of the phosphatidyl inositol 3kinase which activates Akt, enhanced the related apoptosis.

A decrease in Bax as well as p53 expressions have been reported in an in vivo mice model of $\mathrm{B}[\mathrm{a}] \mathrm{P}$-induced skin carcinogenesis [108]. In this in vivo model, the same group has evidenced an increase in the expression of survivin [108]. Such an increased expression also occurred in vitro in hepatoma cells treated with B[a]P [109]. It is worth stressing that survivin belongs to the family of inhibitor of apoptosis proteins (IAPs), which are known to protect cells towards apoptosis by preventing the activation of caspases; furthermore, its expression is strongly upregulated in almost all cancers [110]. Low doses of nitric oxide (NO) have been shown to upregulate the expression of survivin [111]. Accordingly, we have recently found that $\mathrm{B}[\mathrm{a}] \mathrm{P}$ triggered a production of $\mathrm{NO}$ in the 
F258 cells which afforded some protection towards apoptosis [112]. Interestingly, compounds blocking the NO increase, not only enhanced the $\mathrm{B}[\mathrm{a}] \mathrm{P}$-induced cell death, but also prevented the related mitochondrial membrane hyperpolarization [112].

\section{Metabolic reprogramming}

Mitochondrial membrane hyperpolarization has been shown to occur concomitantly to a prosurvival metabolic reprogramming [113], and has been previously linked to carcinogenesis [114]. In F258 hepatic cells treated with $\mathrm{B}[\mathrm{a}] \mathrm{P}$, both hyperpolarization and a Warburg-like effect could be seen, and an inhibition of this latter response increased cell death [115]. In this context, cell reprogramming also appears to be a determinant cell survival pathway. However, more specifically, how such a reprogramming can protect cells to support a carcinogenic phenotype upon exposure to $\mathrm{B}[\mathrm{a}] \mathrm{P}$, remains to decipher. Possible involved mechanisms might be an activation of the pentose phosphate pathway which was activated in F258 cells under these conditions [115]; indeed, such a pathway is known to produce anti-oxidant species such as NADPH $[116,117]$. In line with this, the AhR-agonist 2,3,7,8-tetrachlorodibenzo-p-dioxin (TCDD) was reported to result in metabolic reprogramming along with an enhanced activity of the pentose phosphate pathway, thereby resulting in an increased protection against ROS [118].

During carcinogenesis, defenses against the $\mathrm{B}[\mathrm{a}] \mathrm{P}$-induced oxidative stress might be due to an activation of the transcription factor Nrf2, as shown in HepG2 hepatoma cells [119] or in Caco-2 colon cancer cells [120]. In further support, it has been reported that survival of malignant cells is partly related to hyperactivation of the Nrf2 pathway $[121,122]$. Note that Nrf2 has also been described as a regulator of the pentose phosphate pathway in cancers [123]. As a Warburg effect often occurs during cell transformation [9-12], the metabolic reprogramming seen in the F258 cells might favor the appearance of a transformed phenotype, thereby outlining a new cancer hallmark targeted by $\mathrm{B}[\mathrm{a}] \mathrm{P}$. In support to this hypothesis, the $\mathrm{B}[\mathrm{a}] \mathrm{P}$-elicited glycolytic shift was found to be 
paralleled by the appearance of an Epithelial-to-Mesenchymal Transition (EMT)-like phenotype in F258 cells [115]. Other cell mechanisms might also underlie the cell survival upon B[a]P exposure.

\section{Gap junction intercellular communication}

In B[a]P-treated Hepa1c1c7 hepatoma cells, our group has evidenced an early increase in the connexin 43 (Cx43)-relying gap junction intercellular communication (GJIC), which bears survival signals. Accordingly, inhibition of GJIC by chlordane or through silencing of Cx43 expression enhanced the related apoptosis, by a mechanism possibly involving ERK [124]. GJIC has previously been suggested to constitute an important part of the carcinogenic process. Interestingly, many tumor promoters are found to decrease GIIC, thereby releasing the cells from restricted cell growth [125]. In line with this and in contrast to our data, a previous study did find a decrease in GJIC upon B[a]P in WB-F344 rat liver epithelial cells [126]. The discrepancy between these two studies might be due to the different cell models used, which exhibit large differences in the metabolism of $B[a] P[98,127]$.

In summary, even though the list presently reported is far from being exhaustive, it is clear that $\mathrm{B}[\mathrm{a}] \mathrm{P}$ exposure results in the activation of multiple survival pathways in addition to the cell death signals. In this context, it is the balance between all these signals that will determine cell fate, towards either death or survival, thereby allowing proliferation of pre-neoplastic cells. Regarding proliferation, $\mathrm{B}[\mathrm{a}] \mathrm{P}$ has been shown to exhibit proliferative effects in several human cancer cells such as gastric cancer cells SGC-7901 and MNK-45 [128], lung epithelial cancer cells A549 [129], breast carcinoma cells MCF-7 [130, 131]. Different signaling pathways have been involved in this process, among which activation of AhR receptor, EGFR, ERK and Akt kinases, HIF1 $\alpha$ transcription factor [128130, 132], and also estrogen receptor (ER) in breast cancer cells [131]. Furthermore, it has been proposed that EGFR activation notably upon exposure to $\mathrm{B}[\mathrm{a}] \mathrm{P}$ quinones would involve superoxide anion production [130]. Finally, previous studies have evidenced an AhR-dependent loss of contact inhibition in B[a]P-treated rat hepatic epithelial stem-like WB-F344 cells $[133,134]$; such an effect, 
which appeared to involve an AhR non-genomic pathway, has been previously associated with cell proliferation [135].

\subsection{Effects on progression phase}

EMT is considered to be a process during which cells acquire a malignant potential through activation of the signaling pathways related to enhanced migration and invasion, which is important for progression of primary tumors towards metastases [136]. Regarding the progression phase, a few studies have indicated that B[a]P exposure can favor EMT phenotype. Treatment of lung cancer cells A549 with $1 \mu \mathrm{M}$ of $\mathrm{B}[\mathrm{a}] \mathrm{P}$ for 24 weeks thus increased the expression levels of several genes involved in EMT, such as the transcription factor Twist and vimentin, whereas the expression of E-cadherin was reduced [137]. This study further indicated that, even after removal of B[a]P for 8 weeks, the Ecadherin expression level remained low, in line with the high expression of Twist. In a more recent study using human hepatocellular carcinoma cells SMMC-7721, indications of EMT following a longterm (1 month) treatment with concentrations of $\mathrm{B}[\mathrm{a}] \mathrm{P}$ as low as $0.01 \mathrm{nM}$ were seen, as judged by the reduced expression of E-cadherin and increased levels of the metastasis promoting proteins vimentin, snail and slug [138]. Most interestingly, this latter work further demonstrated a dosedependent increase in cell migration in vitro, and an in vivo induction of metastases after injection of $B[a] P-e x p o s e d$ cells into the tail vein of nude mice. In F258 cells, a low concentration of $B[a] P(50 \mathrm{nM})$ was found to induce an EMT phenotype as soon as $48 \mathrm{~h}$, as seen as changes in cell morphology, Ecadherin and vimentin protein levels, as well as increased cell migration [115]. Regarding the intracellular signaling underlying the B[a]P-induced metastasis, Ba and collaborators [138] observed an involvement of the NFKB pathway in the induced migration of SMMC-7721 cells. Whether NFKB regulates the transcription factor snail under these conditions, as previously reported [139], remains however to be tested. 
Other signaling pathways have also been reported, notably the involvement of a ROSmediated p38 MAPK pathway in the B[a]P-triggered migration of HepG2 cells [140]. In gastric cancer cells SGC-7901 and MNK-45, both AhR and ERK would play a role in the metastasis process induced by $B[a] P$, notably through upregulation of metalloproteinase-9 (MMP-9) [128]. A role for AhR has also been previously proposed in TCDD-induced migration and invasion [141], and involves a nongenomic, Src-kinase-dependent pathway [35]. Likewise, B[a]P has been shown to activate Src kinase in breast cancer cells MDA-MB-231. This activation was related to cell migration, likely through the formation of a FAK (focal adhesion kinase)/Src complex leading to an ERK-dependent activation of MMP-2 and -9 [142]. More recently, the sirtuin SIRT1, which is an histone deacetylase involved in cell metabolism, mitochondrial biogenesis and glycolysis among others [143, 144], has been found to be upregulated by $\mathrm{B}[\mathrm{a}] \mathrm{P}$ in human bronchial epithelial BEAS-2B cells. This upregulation was shown to control cell migration upon $\mathrm{B}[\mathrm{a}] \mathrm{P}$ exposure [145]. Regarding $\mathrm{B}[\mathrm{a}] \mathrm{P}$-induced $\mathrm{EMT}$, a role for the transcription factors FOXA1 and FOXA2, which bind to and open chromatin, might also be proposed; indeed, a recent study showed that long-term exposure to tobacco smoke carcinogens (including $\mathrm{B}[\mathrm{a}] \mathrm{P})$ could lead to EMT as well as to a decrease in the expression of these two factors in human bronchial epithelial cells [146].

In conclusion, the data available so far suggest that B[a]P can trigger many, if not all, cancer hallmarks, including angiogenesis [138], inflammation [147, 148], and escape to immune destruction due to immunotoxic effects of this carcinogen $[149,150]$. As we will detail in section 4 , the mode of action of $B[a] P$ upon several of these hallmarks seems to involve changes in $\mathrm{H}^{+}$homeostasis, as shown by our group.

\section{Benzo[a]pyrene and $\mathrm{H}^{+}$dynamics: a complex story}


Alterations of $\mathrm{H}^{+}$homeostasis represent an important parameter in both physiological and pathological processes, notably in cell death $[7,151]$ and carcinogenesis [8-12]. Based upon this fact, our research on the carcinogenicity of $\mathrm{B}[\mathrm{a}] \mathrm{P}$ led us to test out the possible involvement of intracellular $\mathrm{pH}$ in the phenotypic responses induced by chemically-induced stress, using particularly $\mathrm{B}[\mathrm{a}] \mathrm{P}$ as a model substance.

\subsection{Origin of NHE1-dependent alkalinization}

In rat hepatic epithelial cells F258, B[a]P induced a biphasic change in intracellular $\mathrm{pH}$, with an early NHE1-dependent alkalinization followed by an acidification which originated from mitochondrial dysfunction [86, 92]. Interestingly, a transient alkalinization was also detected in another hepatic cell line, that is the mouse hepatoma cells Hepa1c1c7 [98], as well as upon exposing the F258 cells to the known carcinogenic PAH, 7,12-Dimethylbenz(a)anthracene (DMBA; [92]). Of note, the bicarbonate-dependent acid extruders (such as the $\mathrm{Na}^{+} / \mathrm{HCO}_{3}{ }^{-}$co-transporter) were not found to be involved in the B[a]P-induced alkalinization [92].

\section{NHE1 and lipid raft nanodomains}

Further studies demonstrated that NHE1 might represent a key node in many of the cell responses towards $\mathrm{B}[\mathrm{a}] \mathrm{P}$, being at the crossroad of several metabolisms, namely xenobiotic-, lipidand energy- metabolism. Regarding the xenobiotic metabolism, the activation of NHE1 was found to originate from ROS produced via a CYP-dependent biotransformation of $\mathrm{B}[\mathrm{a}] \mathrm{P}$ [92]. The ROS appeared to act on NHE1 not only via the MAP kinase kinase 4 (MKK4)/c-Jun kinase (JNK) pathway [93], but also through inducing a remodeling of lipid raft nanodomains [152]. In NHE1-overexpressing PS120 fibroblasts, a depletion of cholesterol from the lipid raft nanodomains was found to activate NHE1. This activation was associated with an exit of the protein outside the lipid rafts, and both phenomena were counteracted by exogenous cholesterol [153]. A similar NHE1 exit was observed upon B[a]P exposure not only in F258 cells [154], but also in Hepa1c1c7 cells (unpublished data). The 
NHE1 exit as well as the intracellular alkalinization were inhibited by exposing B[a]P-treated cells not only to cholesterol, but also to mevalonate (the synthesis product of 3-hydroxy-3-methylglutaryl-CoA reductase [HMGCoA reductase], a key enzyme in cholesterol synthesis) [152, 154].

The NHE1 exit outside lipid rafts appeared to favor binding of calmodulin, thus leading to activation of the transporter [154]. Thus, by modulating lipid (cholesterol) metabolism, B[a]P caused a destabilization of lipid rafts, which favored relocation of NHE1 outside raft regions and its activation. Most interestingly, the B[a]P-induced inhibition of HMGCoA reductase was not only linked to ROS production, but also to an activation of AhR. Furthermore, this latter activation was found to down-regulate LXR and SREBP1C, which are two important transcription factors for lipid synthesis [152]. The DNA damage-related p53 pathway did not play any role for NHE1 activation, strongly suggesting a non-genotoxic mechanism for the activation of this $\mathrm{pH}$ regulating transporter [93]. As stated above, the MKK4/JNK pathway and calmodulin both appeared to be involved in the B[a]Pinduced NHE1 activation. However, the initial triggering mechanism and possible crosstalks between these two pathways remain to be clarified.

\subsection{Role of $\mathrm{H}^{+}$homeostasis in $\mathrm{B}[\mathrm{a}] \mathrm{P}$-induced cell death}

\section{Interplay between NHE1 and p53 pathways}

With respect to NHE1 role in the phenotypic responses towards B[a]P exposure, there is an ambivalent role for this transporter, whose activation appears to underlie either pro-death or prosurvival signals. By using cariporide (a specific NHE1 inhibitor) or by silencing the transporter expression in F258 cells, the B[a]P-induced apoptosis was inhibited [92, 93]. Interestingly, we demonstrated that the NHE1-dependent pathway worked together with the DNA damage response/p53-linked pathway to induce apoptosis [86, 92]. The activation of these pathways was followed by a translocation of HKII from mitochondria to cytosol and hence mitochondrial dysfunction [93]. A more detailed study demonstrated a role of the couple GSK3 $\alpha / c-m y c$ in the 
translocation of this enzyme, with a phosphorylation of GSK3 $\alpha$, and consequently a decrease of cmyc expression [99]. It is also interesting to note that a link between inhibition of HMGCoA reductase and c-myc inactivation (both observed upon $\mathrm{B}[\mathrm{a}] \mathrm{P}$ exposure) has been previously reported in human hepatoma-derived cell lines [155]. Regarding the mechanism underlying the HKII translocation from mitochondria to cytosol following c-myc down-regulation, c-Myc is a known regulator of glucose metabolism $[156,157]$, and a reduction of this metabolism is found to result in translocation of HKII $[158,159]$. However, in the B[a]P-treated F258 cell model, an increase in glycolysis was rather seen [115], suggesting that some other mechanisms were involved in this case.

Regarding the role for NHE1 and p53 interplay in the pathway leading to HKII translocation, the molecular mechanisms involved remain to be investigated, especially as these two proteins were independently activated [93]. One might then propose the existence of a protein complex comprising NHE1, GSK3 $\alpha$ and p53, all necessary for c-myc down-regulation [99]. In line with this, NHE1 has been shown to form a signalplex with the kinases PI3K/Akt owing to its scaffold function via its C-terminal tail [160, 161]; this signalplex is responsible for Akt activation [161], thus most likely allowing GSK3 $\alpha / \beta$ phosphorylation [162]. Besides, an interaction between GSK3 $\beta$ and $p 53$ has also been reported in link with apoptosis induction [163]. Taken altogether, these data will deserve further investigation to clarify the interplay between NHE1, p53, GSK3 $\alpha, c-m y c$ and HKII.

Following targeting of HKII by the NHE1 and p53 pathways, the resulting mitochondrial dysfunction was found to lead to an increased production of the superoxide anion and a secondary intracellular acidification [86]. This latter event is likely being involved in the activation of both the caspase-dependent and the LEI/L-DNase II-dependent pathways in B[a]P-treated cells, as stated in section 3.2. Accordingly, Torriglia's group has previously demonstrated an activation of this DNase following an intracellular acidification resulting from NHE1 inhibition in the kidney cells BHK [164].

\section{NHE1 and membrane fluidity}


In our context of cell death, we also demonstrated a role for NHE1 in the changes of bulk membrane fluidity (i.e. the fluidity detected in whole cells) triggered by $\mathrm{B}[\mathrm{a}] \mathrm{P}$. Indeed, cariporide was capable of inhibiting the increase in bulk fluidity detected upon carcinogen treatment [165]. Knowing that this increase in fluidity was involved in the iron uptake and related lipid peroxidation during $\mathrm{B}[\mathrm{a}] \mathrm{P}$-induced cell death [103], one might then suggest that NHE1, besides targeting mitochondria function, would also exert its pro-death action through increasing the bulk membrane fluidity. Note that NHE1 has been previously described as a mechano-sensitive protein [166]. Based upon the fact that NHE1 bears several functions [167], whether the B[a]P-induced membrane fluidization results from the intracellular alkalinization [168], or from its cytoskeleton anchor properties [169] would deserve further investigation.

\section{Mitochondrial dysfunction and acidification}

Besides the biphasic changes in cytosolic $\mathrm{pH}$ induced by $\mathrm{B}[\mathrm{a}] \mathrm{P}$, we more recently detected an important acidification of the mitochondrial matrix in F258 cells (decrease by around $1.5 \mathrm{pH}$ unit). Such an effect might be responsible for the mitochondrial dysfunction, through the impairment of the complex II of the respiratory chain, as observed under our conditions [115]. Indeed, a dissociation of complex II that was dependent on mitochondrial matrix acidification, has been previously observed upon treatment of cancer cells by several anticancer drugs, thus leading to ROS production and apoptosis. Interestingly, overexpressing NHE1 under such conditions not only prevented the change in matrix $\mathrm{pH}$, but also apoptosis [170]. Therefore, we hypothesize a role for $\mathrm{pH}$-dependent complex II alterations also in $\mathrm{B}[\mathrm{a}] \mathrm{P}$-induced apoptosis. Although we observed that NHE1 was also activated by B[a]P in Hepa1c1c7 cells, this activation was not involved in the related apoptosis [98]. This discrepancy is probably due to the much higher concentration of $\mathrm{B}$ [a]P needed to induce apoptosis in Hepa1c1c7 compared to F258 cells. At these high concentrations, the p53 pathway would be predominant due to important DNA damages. This illustrates that different 
signaling pathways are triggered at different $\mathrm{B}[\mathrm{a}] \mathrm{P}$ concentrations, thus resulting in different mechanisms for toxicity as also reported by others $[109,171]$.

\subsection{Role of $\mathrm{H}^{+}$homeostasis in $\mathrm{B}[\mathrm{a}] \mathrm{P}$-induced pre-neoplastic phenotype}

\section{NHE1 and cell transformation}

In addition to its role in apoptosis, which still remains poorly reported (see eg. review [151]), NHE1 activation has been more generally linked to cell transformation and cancer development [9$12,172,173]$. Cancer cells are characterized by a reversal of the $\mathrm{pH}$ gradient, with an acidic extracellular pH (between 6.2 and 6.9), and an alkaline intracellular $\mathrm{pH}$ (between 7.12 and 7.7) [11]. In many cancer cells, an increase in NHE1 activity has been described as participating in the reversal of pH gradient [174]. Reshkin and collaborators [172] have further demonstrated a key role for NHE1 activation in the oncogenic transformation of NIH3T3 mouse embryo fibroblast cells when using the E7 oncogene of human papillomavirus type 16 (HPV16). Indeed, inhibition of NHE1 not only prevented the related intracellular alkalinization, but also prevented other characteristics of neoplastic transformation, notably in vitro cell proliferation and in vivo tumor growth, and increased glycolysis [172]. It is worth emphasizing here that these authors found that the rise in cell proliferation was independent from the glycolytic shift in the human keratinocyte cell line HPKIA.

Regarding $\mathrm{B}[\mathrm{a}] \mathrm{P}$, we have observed a reversal of the $\mathrm{pH}$ gradient in F258 cells, with a NHE1related cytosolic alkalinization and an acidification of extracellular $\mathrm{pH}\left(\mathrm{pH}_{\mathrm{e}}\right)$, both occurring following a 48h-exposure to $\mathrm{B}[\mathrm{a}] \mathrm{P}(50 \mathrm{nM})$ prior to cell death $[92,115]$. A shift towards an EMT-like cell phenotype was concomitantly observed, along with an increase in cell migration [115]. Under those conditions, $\mathrm{B}[\mathrm{a}] \mathrm{P}$ also induced a metabolic reprogramming towards glycolysis along with an inhibition of OXPHOS. Blocking NHE1 with cariporide prevented the glycolytic shift, whereas inhibition of 
glycolysis increased cell death [115]. The alterations in glucose oxidation, which reflected a dysfunction of the TCA cycle, were also prevented by cariporide [115]. Once more, the p53 pathway appeared to work hand by hand with NHE1 since the glycolytic shift induced by B[a]P was blocked when $p 53$ was inhibited either by pifithrin- $\alpha$ or by silencing its expression (Figure 1). With regard to the $\mathrm{B}[\mathrm{a}] \mathrm{P}$-triggered EMT phenotype, this would not be related to NHE1 activation. Indeed, neither the changes in vimentin expression nor the increase in the cell index, as determined by the xCELLigence technology and which reflects the cell spreading triggered by $\mathrm{B}[\mathrm{a}] \mathrm{P}$, were affected by cariporide (Figure $2 \mathrm{~A} \& \mathrm{~B}$ ). In contrast, the $\mathrm{B}[\mathrm{a}] \mathrm{P}$-induced cell migration was prevented by NHE1 inhibition (Figure 2C). Therefore, considering the data published so far, whether NHE1-related metabolic reprogramming would be directly involved in EMT still remains a question of debate. In order to give a clue regarding the appearance of an EMT-like phenotype under our experimental conditions, one might propose that this change could be the result of a transcriptional regulation by AhR of the EMT markers Slug or Snail, as previously reported for B $[a] P$ or TCDD $[175,176]$.

\section{NHE1 and energy metabolism/metabolic reprogramming}

Regarding the role of $\mathrm{pH}$ in controlling cell metabolism, Peak and collaborators [177] have determined that the stimuli which triggered intracellular alkalinization were simultaneously promoting the activation of glycogen synthesis as well as glycolysis in cultures of rat hepatocytes. Later on, a transcriptomic analysis revealed that the proton transport activity of NHE1 was involved in the regulation of the expression of numerous genes, with about $10 \%$ directly related to energetic metabolism [178]. Regarding the carcinogenesis-related Warburg effect, intracellular alkalinization has been shown to be a key regulator in this metabolic reprogramming, favoring the switch from OXPHOS to aerobic glycolysis [179]. More recently, it has been proposed that following the induction of a mild alkalinization, such a reprogramming might stem from an enhancement of HK activity due to an increased amount of HK protein bound to the voltage-dependent anion channel in mitochondria [180]. Such an impact of alkalinization on HK subcellular distribution has also previously 
been demonstrated [181]. Furthermore, an alkaline $\mathrm{pH}$ can affect glycolysis not only by impacting glycolytic enzyme activities such as phosphofructokinase-1 (PFK-1) $[11,179]$, but also by acting on protein-protein interactions. Of note, HKII is known to repress OXPHOS in tumor cells via an action on VDAC closure [182].

Regarding $\mathrm{B}[\mathrm{a}] \mathrm{P}$ effects on glycolysis, a previous study reported that mice exposed to this carcinogen exhibited an increased activity of several enzymes involved in glycolysis in lung [183]. In this context, one might suppose a role for the NHE1 in the observed changes in glycolysis. Accordingly, it has been reported that an activation of NHE1 better preserves mice heart during ischemia-reperfusion by acting on cell metabolism [184].

$\mathrm{B}[\mathrm{a}] \mathrm{P}$-induced metabolic reprogramming in F258 cells was accompanied by an induction of a marked acidification of the mitochondrial matrix [115]. Whereas the origin of this $\mathrm{pH}$ change remains to be determined, it is evident that this one together with the cytosolic alkalinization leads to a marked change of the cytosol-mitochondrial proton gradient $\left(\Delta \mathrm{pH}_{\mathrm{m}}\right)$ necessary for normal functioning of OXPHOS and TCA cycle. Indeed at least ten carriers involved in the regulation of the mitochondrial metabolic activities require a fine tuning of this gradient [11]. In F258 cells the effect of $\mathrm{B}[\mathrm{a}] \mathrm{P}$ on $\Delta \mathrm{pH}_{\mathrm{m}}$ seems to be responsible for the inhibition of OXPHOS [115]. In line with this, we found that $\mathrm{B}[\mathrm{a}] \mathrm{P}$ altered complex II succinate dehydrogenase activity (SDH) without any change in succinate quinone reductase activity (SQR); this would lead to a disconnection between TCA cycle and OXPHOS. The matrix acidification might play a role in these alterations, knowing that similar effects on complex II activities have been previously related to a dissociation of SDH/SQR sub-units following matrix acidification [170]. These alterations of complex II activity have been shown to be associated with an increase in succinate level $[185,186]$, as observed under our conditions [115]. Of note, an increase in succinate level is known to play a role in tumorigenesis, as recently reviewed [187]. 
With regard to mitochondrial matrix $\mathrm{pH}$, it has been established that the proton-motive force $\Delta p$, necessary for the functioning of the respiratory chain, depends on both $\Delta \mathrm{pH}_{\mathrm{m}}$ and $\Delta \psi_{\mathrm{m}}$. The relative contribution of $\Delta \mathrm{pH}_{\mathrm{m}}$ and $\Delta \psi_{\mathrm{m}}$ to the $\Delta \mathrm{p}$ was estimated to be about $30 \%$ and $70 \%$ respectively, suggesting that $\Delta \psi_{\mathrm{m}}$ is the main component of $\Delta \mathrm{p}$ [188]. The molecule FCCP (Carbonyl cyanide 4-(trifluoromethoxy)-phenylhydrazone), a known uncoupling agent that dissipates the proton gradient, suppresses both $\Delta \mathrm{pH}_{\mathrm{m}}$ and $\Delta \psi_{\mathrm{m}}$ and hence $\Delta \mathrm{p}$ [189]. In contrast, the $\mathrm{K}^{+} / \mathrm{H}^{+}$ ionophore nigericin, which leads to an acidification of the mitochondrial matrix, suppresses $\Delta \mathrm{pH}_{\mathrm{m}}$ and increases $\Delta \psi_{\mathrm{m}}$ in order to maintain $\Delta \mathrm{p}$. Taken this into consideration along with the $\mathrm{B}[\mathrm{a}] \mathrm{P}$ induced $\Delta \mathrm{pH}_{\mathrm{m}}$ alterations, we suggest that the NO-dependent $\Delta \psi_{\mathrm{m}}$ increase [112] might be a compensatory response to the alterations in $\Delta \mathrm{pH}_{\mathrm{m}}$ This would enhance the capacity of the mitochondria to preserve, or at least reduce the impact of the carcinogen on $\Delta p$ and hence on the ATP synthesis.

The transfer of charges involved in the $\mathrm{B}[\mathrm{a}] \mathrm{P}$-induced hyperpolarization might include the exchange of $\mathrm{Na}^{+} / \mathrm{H}^{+}$ions, as the $\mathrm{B}[\mathrm{a}] \mathrm{P}$-induced NHE1 activation was responsible for the secondary mitochondria-dependent cytosolic acidification $[86,92]$. If so, the effects of $B[a] P$ on TCA cycle might involve a mitochondrial NHE1 isoform (mNHE1). Indeed, this isoform, which is also sensitive to cariporide [190], has previously been described to play a role in the regulation of mitochondrial pH in cardiac tissue [191, 192]. Thus, mNHE1 activation leads to a proton influx into the mitochondrial matrix [192]. Furthermore, these authors have suggested a role for this mitochondrial isoform in directing cell fate towards survival. Indeed, the activity thereof appeared to prevent the opening of mPTP (mitochondrial permeability transition pore) upon calcium stimulation, and could therefore also be involved in the maintenance of $\Delta \Psi_{\mathrm{m}}$ [192]. Based upon these data, it would be interesting to determine whether mNHE1 could be involved in $\mathrm{B}[\mathrm{a}] \mathrm{P}$-induced matrix acidification.

Finally, with regard to the possible impact of the B[a]P-induced extracellular acidification, it is worth stressing that a low pHe is reported to facilitate the acquisition of chromosomal aberrations 
[193]. Furthermore, low pHe has been suggested to alter several other cell processes, including DNA repair [194], inflammatory response of tumors [195], or cell death [196]. Thus, the B[a]P-induced extracellular acidification might also participate to the carcinogenicity of this PAH, and so would deserve further investigation.

Altogether, our results clearly point to alterations of $\mathrm{H}^{+}$dynamics as possible major determinants in the carcinogenic effects of $B[a] P$.

\section{Concluding remarks and next challenges}

Our work on the carcinogenic effects of $\mathrm{B}[\mathrm{a}] \mathrm{P}$ has demonstrated for the first time: (1) that an environmental human carcinogen may activate NHE1 through a membrane remodeling because of alterations of lipid metabolism which stem from both ROS production due to metabolic activation by CYPs and Ahr activation; (2) that the activation of NHE1 seems to be a central modulator of the cellular responses towards this carcinogen, notably by acting on energy metabolism (Figure 3), cell death/survival balance and on various cell transformation pathways. However several important questions remain to be tackled.

\subsection{Is NHE1 activation important for other cancer hallmarks triggered by $B[a] P$ ?}

Based upon the litterature, it clearly appears that cancer hallmarks other than those we have already analyzed, are targeted by both B[a]P exposure and NHE1 activation (Figure 4). Indeed, NHE1 activation has been previously shown to target several of the cancer hallmarks previously defined by Hanahan \& Weinberg [6], as recently reviewed by several groups [9-12]. Notably, NHE1 is capable of promoting cell survival, through activation of the Akt $[161,197]$, or ERK pathways $[198,199]$. This transporter also plays a role in cell migration [200], through regulating both the formation of focal adhesion points and extracellular matrix degradation [201, 202]. NHE1 is also involved in the 
regulation of invasiveness processes of tumors [203]. Such an action might result from the activation of membrane channels, as demonstrated in breast cancer cells where the expression of the $\mathrm{Na}^{+}$ channels Nav1.5 was responsible for the allosteric modulation of NHE1 [204]. Interestingly, in the metastatic cell line MDA-MB-231, the co-localization of NHE1, EGFR, B1-integrin and phosphorylatedNHERF1 in invadopodia lipid rafts has been suggested to regulate invadopodia actin cytoskeleton dynamics/activity [205]. Moreover, NHE1 action on tumor invasiveness appeared to be based on modulation of MMP activity [206, 207]. It appears that the action of NHE1 during the invasion process requires a glycolytic production of ATP [208], knowing that this ATP production was found to be localized within the invadopodia of cancer cells [209]. NHE1 has also been shown to be involved in angiogenesis process [210], and would possibly be a regulator of inflammatory processes [211, 212]. Therefore, it appears that many cancer hallmarks are shared by both B[a]P exposure and NHE1 activation (Figure 4). In this context, it will be interesting to determine whether NHE1 activation might also be involved in the B[a]P-induced cancer hallmarks not analyzed yet and detailed in Part 3 of the present review. This is important to consider since this might lead proposing cariporide or other NHE1 potent inhibitors to prevent B[a]P- or other chemicals-induced carcinogenesis [213].

\subsection{What are the molecular mechanisms underlying the ambivalent role of NHE1 activation in the control of the cell death/survival balance upon B[a]P exposure?}

Regarding the role of NHE1 in $\mathrm{B}[\mathrm{a}] \mathrm{P}$-induced cell responses, we have demonstrated that activation of this transporter can trigger both cell death as well as cell survival signals in the same cells $[86,92,93,115]$. In this context, our data raise the question about how a similar NHE1 activation can play such an ambivalent role under those conditions. One clue might come from the different functions of NHE1 $[160,214]$. Thus, whereas a role for NHE1 as a scaffold protein and anchor protein might be put forward for the $\mathrm{B}[\mathrm{a}] \mathrm{P}$-induced cell death, its function as an $\mathrm{H}^{+}$extruder (that is, a direct action on $\mathrm{pH}_{\mathrm{i}}$ ) might explain its role in the $\mathrm{B}[\mathrm{a}] \mathrm{P}$-induced cell survival related to metabolic reprogramming. 
In line with this double role, another question is about the exact role for the sub-membrane location of NHE1 inside or outside the lipid rafts. Is the exit of NHE1 necessary for cell death to occur or is this just a mean for the chemical to activate NHE1, whatever its role? Our study on the impact of B[a]P in Hepa1c1c7 cells can shed some light on this. Indeed, like in F258 cells [154], our data showed an activation of NHE1 in this cell model, along with its exit outside lipid rafts (unpublished data). However, NHE1 activation was found to play no role in the related cell death in those hepatoma cells [98], but appeared to be involved in the lactate production observed under those conditions [115]. Therefore, it seems that the NHE1 exit ouside lipid rafts upon B[a]P exposure would merely relate to the growth factor-independent mode of NHE1 activation that we previously demonstrated [153, 166]. Nonetheless, a possible role for such an exit in the formation of a pro-death signalplex cannot be ruled out yet.

Another interesting point to emphasize regarding NHE1 sub-membrane location concerns the increase in gap junction intercellular communication (GJIC) observed in B[a]P-treated Hepa1c1c7 cells [127]. Indeed, our data have shown that, like for NHE1, B[a]P induced an exit of connexin 43 outside lipid rafts in order to form active junctional plaques. Based upon the fact that, in cardiac cells, NHE1 is known to be localized in close proximity to $\mathrm{CX} 43$ [215] and that $\mathrm{H}^{+}$is involved in the control of Cx43-dependent GJIC [216, 217], one might propose that the survival signal relying upon the $\mathrm{B}[\mathrm{a}] \mathrm{P}$-induced increase in GJIC might also involve NHE1 activation. Therefore, in future studies dealing with GJIC during carcinogenesis, it would be interesting to clarify the role of $\mathrm{H}^{+}$dynamics and NHE1 activity in this process.

\subsection{Is NHE1 activation a general phenomenon upon exposure to environmental chemicals that may affect membrane characteristics?}

Regarding NHE1 activation by $\mathrm{B}[\mathrm{a}] \mathrm{P}$, as stated above, we demonstrated an important role in the regulation of this transporter for alterations in lipid metabolism, thereby resulting in membrane 
remodeling $[152,154]$. We have previously shown that another carcinogenic PAH, i.e. DMBA (50 nM), was also capable of inducing both intracellular alkalinization and apoptotic cell death [92] as well as a NHE1-dependent increase in lactate production [115]. Whether the activation of NHE1 upon DMBA exposure would rely on membrane remodeling remains however to be determined. In support to this hypothesis, it is worth stressing that this carcinogen has been previously shown to affect lipid metabolism, especially cholesterol synthesis [218]. Should any carcinogen-induced membrane remodeling be an important regulator of NHE1 activity, it would then be essential to enlarge the kind of studies we have performed to environmental contaminants other than B[a]P. Indeed, it has been shown that many of these molecules can affect membrane physicochemical characteristics [219, 220]. For example, a low concentration of arsenic trioxide has been shown to increase $\mathrm{pH}_{\mathrm{i}}$ as well as proliferation in Madin-Darby canine kidney MDCK cells via NHE (likely NHE1) activation [221]. As this metalloid contaminant can alter lipid metabolism [222], one might then propose a role for membrane remodeling in NHE activation. More recently, a Warburg effect has also been evidenced in arsenic-treated non-malignant pulmonary epithelial cell line BEAS-2B [223]. Furthermore, an upregulation of cell energy metabolism in $\mathrm{B}[\mathrm{a}] \mathrm{P} /$ arsenic-transformed lung epithelial cells has been reported [224]. Thus, it would be worth testing the role of NHE1 in the carcinogenic effects of arsenic as well as many other carcinogenic compounds, notably when present in chemical mixtures.

\subsection{How does the triad NHE1/Aryl hydrocarbon Receptor/p53 work together to} control B[a]P-induced cell responses?

Another important question to solve is the interplay between NHE1, AhR and p53, with respect to the control of the equilibrium between cell death and survival signals. Indeed, our data have evidenced a role for both p53 and AhR in concert with NHE1, in the B[a]P-induced apoptosis as well as metabolic reprogramming. Our previous work identified that AhR was involved in B[a]Pinduced NHE1 activation via its role in membrane remodeling through the regulation of HMGCoA reductase expression $[152,154]$. Therefore, one might suppose an action of AhR on cell death and 
glycolytic reprogramming through NHE1 activation. However, a pool of mitochondrial AhR has been evidenced, which is bound to the ATP5a1 sub-unit of the FOF1 ATPase [37, 38]. Interestingly, activation of AhR by TCDD led to a mitochondrial hyperpolarization [37], similarly to what we observed with $B[a] P[112,225]$. In this context, a role for the mitochondrial pool of AhR might also be involved, through the control of the ATPase activity, and thus might co-regulate cell energy metabolism in concert with changes in $\mathrm{H}^{+}$dynamics.

With respect to $\mathrm{p} 53$, this tumor suppressor is well recognized as playing a critical role in the control of many cellular processes including apoptosis, cell cycle arrest, genome stability, and angiogenesis $[226,227]$. The p53 capacity to regulate cell metabolism has extensively been described, notably in the regulation of both glucose transport [228], glycolysis via TIGAR expression [229], pentose phosphate pathway , TCA cycle, glutamine metabolism [230], or even in the control of OXPHOS [231], by interacting with complex $\mathrm{V}$ [232]. However, p53 is generally given as limiting glycolysis and improving oxidative phosphorylation [226]. In F258 cells, we observed that the p53 activation by $\mathrm{B}[\mathrm{a}] \mathrm{P}$ could also play a role in promoting cell survival notably in close relationship with the metabolic reprogramming. Such an effect of p53 on metabolism reorientation is in contrast to what is classically described. In order to give an explanation to these opposite effects, one might propose that the action of $\mathrm{p} 53$ on the glycolytic shift detected in B[a]P-treated F258 cells would rather go through a direct effect of this protein on the transcriptional activity of AhR, as previously evidenced [233]. Besides, if the involvement of p53 in regulating cell metabolism is now well established, the mechanims appear to be quite complex since the p53 status can direct the type of cell response [234, 235]. Indeed, it has been shown for example that mutant p53 can induce a Warburg effect [235]. Thus, a characterization of the p53 status in our cell models should be performed.

Finally, we have shown that in F258 cells, both an inhibition of either NHE1 or p53 prevented the $\mathrm{B}[\mathrm{a}] \mathrm{P}$-induced cell death $[86,92,93]$. Such a prevention was also found with regard to metabolic 
reprogramming, which is considered to be a survival pathway [115]. However, cariporide does not seem to prevent the $\mathrm{B}[\mathrm{a}] \mathrm{P}$-induced EMT-like phenotype (Figure 2). A possible role for $\mathrm{p} 53$ in this process remains to be elucidated. These points are important to consider, since we have previously shown that NHE1 inhibition was involved in the protective effect of omega-3 towards B[a]P-induced apoptosis but without affecting DNA damage [236]. In this context, one important question to clarify concerns the possible consequences of an inhibition of NHE1 following exposure to environmental carcinogens, since this theoretically seems to favor the selection of pre-neoplastic cells and hence cancer formation.

\section{Acknowledgements}

We wish to warmly thank Sylvie Bortoli and Samantha Antonio (UMR Inserm 1124, Université Paris Descartes) for their scientific input with regard to the xCELLigence experiments. We are also very grateful to Martine Chevanne, Isabelle Gallais and Morgane Fernier for their daily technical help. We finally want to warmly thank Drs Xavier Tekpli, Morgane Gorria and Béatrice Dendelé for their important contribution to our project. This work was financially supported by the French Ministry of Research, Région Bretagne, the Ligue contre le Cancer, and the French National Agency for Research (ANR; STEATOX project: “ANR-13-CESA-0009). 


\section{References}

[1] Waldron HA. A brief history of scrotal cancer. $\mathrm{Br} J$ Ind Med 1983;40:390-401. doi:10.1136/oem.40.4.390.

[2] Mazzanti R, Arena U, Tassi R. Hepatocellular carcinoma: Where are we? World J Exp Med 2016;6:21-36. doi: 10.5493/wjem.v6.i1.21.

[3] WHO. An overview of the evidence on environmental and occupational determinants of cancer. 2011, Spain. International conference on Environmental and Occupational determinants of cancer: Interventions for primary prevention (conference document).

[4] Goodson WH 3rd, Lowe L, Carpenter DO, Gilbertson M, Manaf Ali A, Lopez de Cerain Salsamendi $A$, et al. Assessing the carcinogenic potential of low-dose exposures to chemical mixtures in the environment: the challenge ahead. Carcinogenesis 2015;36 Suppl 1:S254-96. doi: 10.1093/carcin/bgv039.

[5] Miller MF, Goodson WH 3rd, Manjili MH, Kleinstreuer N, Bisson WH, Lowe L. Low-Dose Mixture Hypothesis of Carcinogenesis Workshop: Scientific Underpinnings and Research Recommendations. Environ Health Perspect 2016 Aug 12. [Epub ahead of print]. doi: 10.1289/EHP411.

[6] Hanahan D, Weinberg RA. Hallmarks of cancer: the next generation. Cell 2011;144:646-74. doi: 10.1016/j.cell.2011.02.013.

[7] Lagadic-Gossmann D, Huc L, Lecureur V. Alterations of intracellular pH homeostasis in apoptosis: origins and roles. Cell Death Differ 2004;11:953-61. doi: 10.1016/j.cell.2011.02.013.

[8] Webb BA, Chimenti M, Jacobson MP, Barber DL. Dysregulated pH: a perfect storm for cancer progression. Nat Rev Cancer 2011;11:671-7. doi: 10.1038/nrc3110.

[9] Parks SK, Chiche J, Pouysségur J. Disrupting proton dynamics and energy metabolism for cancer therapy. Nat Rev Cancer 2013;13:611-23. doi: 10.1038/nrc3579.

[10] Alfarouk KO, Verduzco D, Rauch C, Muddathir AK, Adil HH, Elhassan GO, et al. Glycolysis, tumor metabolism, cancer growth and dissemination. A new $\mathrm{pH}$-based etiopathogenic perspective and therapeutic approach to an old cancer question. Oncoscience 2014;1:777-802. eCollection 2014. doi: 10.18632/oncoscience.109.

[11] Reshkin SJ, Greco MR, Cardone RA. Role of $\mathrm{pHi}$, and proton transporters in oncogene-driven neoplastic transformation. Philos Trans R Soc Lond B Biol Sci 2014;369(1638):20130100. doi: 10.1098/rstb.2013.0100.

[12] Counillon L, Bouret $\mathrm{Y}$, Marchiq I, Pouysségur J. $\mathrm{Na}(+) / \mathrm{H}(+)$ antiporter (NHE1) and lactate/H(+) symporters (MCTs) in $\mathrm{pH}$ homeostasis and cancer metabolism. Biochim Biophys Acta 2016;1863:2465-80. doi: 10.1016/j.bbamcr.2016.02.018.

[13] Alexander J, Benford D, Cockburn A, Cravedi J-P, Dogliotti E, Di Domenico A, et al. Polycyclic Aromatic Hydrocarbons in Food - Scientific Opinion of the Panel on Contaminants in the Food Chain. The EFSA Journal 2008;724:1-114. 
[14] Neal J, Rigdon RH. Gastric tumors in mice fed benzo(a)pyrene: a quantitative study. Tex Rep Biol Med. 1967;25:553-7.

[15] Brune H, Deutsch-Wenzel RP, Habs M, Ivankovic S, Schmähl D. Investigation of the tumorigenic response to benzo(a)pyrene in aqueous caffeine solution applied orally to Sprague-Dawley rats. J Cancer Res Clin Oncol 1981;102:153-7.

[16] Wester PW, Muller JJ, Slob W, Mohn GR, Dortant PM, Kroese ED. Carcinogenic activity of benzo[a]pyrene in a 2 year oral study in Wistar rats. Food Chem Toxicol 2012;50:927-35. doi: 10.1016/j.fct.2011.12.003.

[17] Moorthy B, Chu C, Carlin DJ. Polycyclic aromatic hydrocarbons: from metabolism to lung cancer. Toxicol Sci. 2015;145:5-15. doi: 10.1093/toxsci/kfv040.

[18] Falcó G, Domingo JL, Llobet JM, Teixidó A, Casas C, Müller L. Polycyclic aromatic hydrocarbons in foods: human exposure through the diet in Catalonia, Spain. J Food Prot 2003;66:2325-31.

[19] Phillips DH. Polycyclic aromatic hydrocarbons in the diet. Mutat Res 1999;443:139-47.

[20] Menzie CA, Potocki BB, Santodonato J. Exposure to carcinogenic PAHs in the environment. Environ Sci Technol 1992;26:1278-84. doi: 10.1021/es00031a002

[21] Ramesh A, Walker SA, Hood DB, Guillén MD, Schneider K, Weyand EH. Bioavailability and risk assessment of orally ingested polycyclic aromatic hydrocarbons. Int J Toxicol 2004;23:301-33. doi: 10.1080/10915810490517063.

[22] Harris KL, Banks LD, Mantey JA, Huderson AC, Ramesh A. Bioaccessibility of polycyclic aromatic hydrocarbons: relevance to toxicity and carcinogenesis. Expert Opin Drug Metab Toxicol 2013;9:1465-80. doi: 10.1517/17425255.2013.823157.

[23] Goulaouic S, Foucaud L, Bennasroune A, Laval-Gilly P, Falla J. Effect of polycyclic aromatic hydrocarbons and carbon black particles on pro-inflammatory cytokine secretion: impact of PAH coating onto particles. J Immunotoxicol 2008;5:337-45. doi: 10.1080/15476910802371016.

[24] Skupińska K, Misiewicz I, Kasprzycka-Guttman T. Polycyclic aromatic hydrocarbons: physicochemical properties, environmental appearance and impact on living organisms. Acta Pol Pharm 2004;61:233-40.

[25] Kim KH, Jahan SA, Kabir E, Brown RJ. A review of airborne polycyclic aromatic hydrocarbons (PAHs) and their human health effects. Environ Int 2013;60:71-80. doi: 10.1016/j.envint.2013.07.019.

[26] Abdel-Shafy HI, Mansour MSM. A review on polycyclic aromatic hydrocarbons: Source, environmental impact, effect on human health and remediation. Egyptian Journal of Petroleum 2016;25:107-23. doi: 10.1016/j.ejpe.2015.03.011.

[27] Guyot E, Chevallier A, Barouki R, Coumoul X. The AhR twist: ligand-dependent AhR signaling and pharmaco-toxicological implications. Drug Discov Today 2013;18:479-86. doi: 10.1016/j.drudis.2012.11.014.

[28] Esser C, Rannug A. The aryl hydrocarbon receptor in barrier organ physiology, immunology, and toxicology. Pharmacol Rev 2015;67:259-79. doi: 10.1124/pr.114.009001. 
[29] Liu Z, Wu X, Zhang F, Han L, Bao G, He X, et al. AhR expression is increased in hepatocellular carcinoma. J Mol Histol 2013;44:455-61. doi: 10.1007/s10735-013-9495-6.

[30] Safe S, Lee SO, Jin UH. Role of the aryl hydrocarbon receptor in carcinogenesis and potential as a drug target. Toxicol Sci 2013;135:1-16. doi: 10.1093/toxsci/kft128.

[31] Wang Q, Xue Y. Characterization of solid tumors induced by polycyclic aromatic hydrocarbons in mice. Med Sci Monit Basic Res 2015;21:81-5. doi: 10.12659/MSMBR.893945.

[32] Nakatsuru Y, Wakabayashi K, Fujii-Kuriyama Y, Ishikawa T, Kusama K, Ide F. Dibenzo[A,L]pyreneinduced genotoxic and carcinogenic responses are dramatically suppressed in aryl hydrocarbon receptor-deficient mice. Int J Cancer 2004;112:179-83. doi: 10.1002/ijc.20365.

[33] Shimada T, Fujii-Kuriyama Y. Metabolic activation of polycyclic aromatic hydrocarbons to carcinogens by cytochromes P450 1A1 and 1B1. Cancer Sci 2004;95:1-6.

[34] Shimada T, Guengerich FP. Inhibition of human cytochrome P450 1A1-, 1A2-, and 1B1-mediated activation of procarcinogens to genotoxic metabolites by polycyclic aromatic hydrocarbons. Chem Res Toxicol 2006;19:288-94. doi: 10.1021/tx050291v.

[35] Tomkiewicz C, Herry L, Bui LC, Métayer C, Bourdeloux M, Barouki R, et al. The aryl hydrocarbon receptor regulates focal adhesion sites through a non-genomic FAK/SrC pathway. Oncogene 2013;32:1811-20. doi: 10.1038/onc.2012.197.

[36] Rey-Barroso J, Alvarez-Barrientos A, Rico-Leo E, Contador-Troca M, Carvajal-Gonzalez JM, Echarri A, et al. The Dioxin receptor modulates Caveolin-1 mobilization during directional migration: role of cholesterol. Cell Commun Signal 2014;12:57. doi: 10.1186/s12964-014-0057-7.

[37] Tappenden DM, Lynn SG, Crawford RB, Lee K, Vengellur A, Kaminski NE, et al. The aryl hydrocarbon receptor interacts with ATP $5 \alpha 1$, a subunit of the ATP synthase complex, and modulates mitochondrial function. Toxicol Appl Pharmacol 2011;254:299-310. doi: 10.1016/j.taap.2011.05.004.

[38] Hwang HJ, Dornbos P, Steidemann M, Dunivin TK, Rizzo M, LaPres JJ. Mitochondrial-targeted aryl hydrocarbon receptor and the impact of 2,3,7,8-tetrachlorodibenzo-p-dioxin on cellular respiration and the mitochondrial proteome. Toxicol Appl Pharmacol 2016;304:121-32. doi: 10.1016/j.taap.2016.04.005.

[39] Bláha L, Machala M, Vondrácek J, Breineková K. Multiple oxidative stress parameters are modulated in vitro by oxygenated polycyclic aromatic hydrocarbons identified in river sediments. Adv Exp Med Biol 2001;500:225-8.

[40] Baird WM, Hooven LA, Mahadevan B. Carcinogenic polycyclic aromatic hydrocarbon-DNA adducts and mechanism of action. Environ Mol Mutagen 2005;45:106-14. doi: 10.1002/em.20095.

[41] Landvik NE, Arlt VM, Nagy E, Solhaug A, Tekpli X, Schmeiser HH, et al. 3-Nitrobenzanthrone and 3-aminobenzanthrone induce DNA damage and cell signaling in Hepa1c1c7 cells. Mutat Res 2010;684:11-23. doi: 10.1016/j.mrfmmm.2009.11.004.

[42] Phillips TD, Richardson M, Cheng YS, He L, McDonald TJ, Cizmas LH, et al. Mechanistic relationships between hepatic genotoxicity and carcinogenicity in male B6C3F1 mice treated with polycyclic aromatic hydrocarbon mixtures. Arch Toxicol 2015;89:967-77. doi: 10.1007/s00204-0141285-8. 
[43] Rossner P, Strapacova S, Stolcpartova J, Schmuczerova J, Milcova A, Neca J, et al. Toxic Effects of the Major Components of Diesel Exhaust in Human Alveolar Basal Epithelial Cells (A549). Int J Mol Sci 2016;17(9). pii: E1393. doi: 10.3390/ijms17091393.

[44] Rodriguez H, Loechler EL. Mutagenesis by the (+)-anti-diol epoxide of benzo[a]pyrene: what controls mutagenic specificity? Biochemistry 1993;32:1759-69.

[45] Conney AH, Chang RL, Cui XX, Schiltz M, Yagi H, Jerina DM, et al. Dose-dependent differences in the profile of mutations induced by carcinogenic $(R, S, S, R)$ bay- and fjord-region diol epoxides of polycyclic aromatic hydrocarbons. Adv Exp Med Biol 2001;500:697-707.

[46] Dong H, Bonala RR, Suzuki N, Johnson F, Grollman AP, Shibutani S. Mutagenic potential of benzo[a]pyrene-derived DNA adducts positioned in codon 273 of the human P53 gene. Biochemistry 2004;43:15922-8. doi: 10.1021/bi0482194.

[47] Poulsen HE, Prieme H, Loft S. Role of oxidative DNA damage in cancer initiation and promotion. Eur J Cancer Prev 1998;7:9-16.

[48] Henkler F, Brinkmann J, Luch A. The role of oxidative stress in carcinogenesis induced by metals and xenobiotics. Cancers (Basel) 2010;2:376-96. doi: 10.3390/cancers2020376.

[49] Henkler F, Stolpmann K, Luch A. Exposure to polycyclic aromatic hydrocarbons: bulky DNA adducts and cellular responses. EXS 2012;101:107-31. doi: 10.1007/978-3-7643-8340-4_5.

[50] Rich T, Allen RL, Wyllie AH. Defying death after DNA damage. Nature 2000;407:777-83. doi: $10.1038 / 35037717$.

[51] LeBoeuf RA, Kerckaert GA, Aardema MJ, Gibson DP, Brauninger R, Isfort RJ. The pH 6.7 Syrian hamster embryo cell transformation assay for assessing the carcinogenic potential of chemicals. Mutat Res 1996;356:85-127.

[52] LeBoeuf RA, Lin PY, Kerckaert G, Gruenstein E. Intracellular acidification is associated with enhanced morphological transformation in Syrian hamster embryo cells. Cancer Res 1992;52:144-8.

[53] Shimada T. Xenobiotic-metabolizing enzymes involved in activation and detoxification of carcinogenic polycyclic aromatic hydrocarbons. Drug Metab Pharmacokinet 2006;21:257-76.

[54] Ying W, Han SK, Miller JW, Swanson RA. Acidosis potentiates oxidative neuronal death by multiple mechanisms. J Neurochem 1999;73:1549-56.

[55] Pekun TG, Hrynevich SV, Waseem TV, Fedorovich SV. Role of iron, zinc and reduced glutathione in oxidative stress induction by low pH in rat brain synaptosomes. Springerplus 2014;3:560. doi: 10.1186/2193-1801-3-560.

[56] Goldman A, Shahidullah M, Goldman D, Khailova L, Watts G, Delamere N, et al. A novel mechanism of acid and bile acid-induced DNA damage involving $\mathrm{Na}+\mathrm{H}+$ exchanger: implication for Barrett's oesophagus. Gut 2010;59:1606-16. doi: 10.1136/gut.2010.213686.

[57] Boström CE, Gerde P, Hanberg A, Jernström B, Johansson C, Kyrklund T, et al. Cancer risk assessment, indicators, and guidelines for polycyclic aromatic hydrocarbons in the ambient air. Environ Health Perspect 2002;110 Suppl 3:451-88. 
[58] International Agency for Research on Cancer (IARC). Some non-heterocyclic polycyclic aromatic hydrocarbons and some related exposures. IARC Monographs 2010;92. Lyon, France.

[59] Bergers G, Hanahan D, Coussens LM. Angiogenesis and apoptosis are cellular parameters of neoplastic progression in transgenic mouse models of tumorigenesis. Int J Dev Biol 1998;42:9951002.

[60] Oliveira PA, Colaço A, Chaves R, Guedes-Pinto H, De-La-Cruz P LF, Lopes C. Chemical carcinogenesis. An Acad Bras Cienc 2007;79:593-616.

[61] Yang SC, Jenq SN, Kang ZC, Lee H. Identification of benzo[a]pyrene 7,8-diol 9,10-epoxide N2deoxyguanosine in human lung adenocarcinoma cells exposed to cooking oil fumes from frying fish under domestic conditions. Chem Res Toxicol 2000;13:1046-50.

[62] Chen SY, Wang LY, Lunn RM, Tsai WY, Lee PH, Lee CS, et al. Polycyclic aromatic hydrocarbonDNA adducts in liver tissues of hepatocellular carcinoma patients and controls. Int J Cancer 2002;99:14-21.

[63] Hodek P, Koblihová J, Kizek R, Frei E, Arlt VM, Stiborová M. The relationship between DNA adduct formation by benzo[a]pyrene and expression of its activation enzyme cytochrome P450 1A1 in rat. Environ Toxicol Pharmacol 2013;36:989-96. doi: 10.1016/j.etap.2013.09.004.

[64] Su Y, Zhao B, Guo F, Bin Z, Yang Y, Liu S, et al. Interaction of benzo[a]pyrene with other risk factors in hepatocellular carcinoma: a case-control study in Xiamen, China. Ann Epidemiol 2014;24:98-103. doi: 10.1016/j.annepidem.2013.10.019.

[65] Rojas M, Marie B, Vignaud JM, Martinet N, Siat J, Grosdidier G, et al. High DNA damage by benzo[a]pyrene 7,8-diol-9,10-epoxide in bronchial epithelial cells from patients with lung cancer: comparison with lung parenchyma. Cancer Lett 2004;207:157-63. doi: 10.1016/j.canlet.2003.11.016.

[66] Puisieux A, Lim S, Groopman J, Ozturk M. Selective targeting of p53 gene mutational hotspots in human cancers by etiologically defined carcinogens. Cancer Res 1991;51:6185-9.

[67] Cherpillod P, Amstad PA. Benzo[a]pyrene-induced mutagenesis of p53 hot-spot codons 248 and 249 in human hepatocytes. Mol Carcinog 1995;13:15-20.

[68] Denissenko MF, Pao A, Tang M, Pfeifer GP. Preferential formation of benzo[a]pyrene adducts at lung cancer mutational hotspots in P53. Science. 1996;274:430-2.

[69] Menzies GE, Reed SH, Brancale A, Lewis PD. Base damage, local sequence context and TP53 mutation hotspots: a molecular dynamics study of benzo[a]pyrene induced DNA distortion and mutability. Nucleic Acids Res 2015;43:9133-46. doi: 10.1093/nar/gkv910.

[70] Tretyakova N, Matter B, Jones R, Shallop A. Formation of benzo[a]pyrene diol epoxide-DNA adducts at specific guanines within K-ras and p53 gene sequences: stable isotope-labeling mass spectrometry approach. Biochemistry 2002;41:9535-44.

[71] Backer JM, Weinstein IB. Interaction of benzo(a)pyrene and its dihydrodiol-epoxide derivative with nuclear and mitochondrial DNA in C3H10T 1/2 cell cultures. Cancer Res 1982;42:2764-9.

[72] Bansal S, Leu AN, Gonzalez FJ, Guengerich FP, Chowdhury AR, Anandatheerthavarada HK, et al. Mitochondrial targeting of cytochrome P450 (CYP) $1 B 1$ and its role in polycyclic aromatic 
hydrocarbon-induced mitochondrial dysfunction. J Biol Chem 2014;289:9936-51. doi: 10.1074/jbc.M113.525659.

[73] Larsen NB, Rasmussen M, Rasmussen LJ. Nuclear and mitochondrial DNA repair: similar pathways? Mitochondrion 2005;5:89-108. doi: 10.1016/j.mito.2005.02.002.

[74] Valente WJ, Ericson NG, Long AS, White PA, Marchetti F, et al. Mitochondrial DNA exhibits resistance to induced point and deletion mutations. Nucleic Acids Res 2016 Aug 22. pii: gkw716. [Epub ahead of print]. doi: 10.1093/nar/gkw716.

[75] Zhang L, Jin Y, Huang M, Penning TM. The Role of Human Aldo-Keto Reductases in the Metabolic Activation and Detoxication of Polycyclic Aromatic Hydrocarbons: Interconversion of PAH Catechols and PAH o-Quinones. Front Pharmacol 2012;3:193. doi: 10.3389/fphar.2012.00193.

[76] Cavalieri EL, Rogan EG. Central role of radical cations in metabolic activation of polycyclic aromatic hydrocarbons. Xenobiotica 1995;25:677-88. doi: 10.3109/00498259509061885.

[77] Sen S, Bhojnagarwala P, Francey L, Lu D, Penning TM, Field J. p53 Mutagenesis by benzo[a]pyrene derived radical cations. Chem Res Toxicol. 2012;25:2117-26. doi: 10.1021/tx300201p.

[78] Reed M, Monske M, Lauer F, Meserole S, Born J, Burchiel S. Benzo[a]pyrene diones are produced by photochemical and enzymatic oxidation and induce concentration-dependent decreases in the proliferative state of human pulmonary epithelial cells. J Toxicol Environ Health A 2003;66:1189-205. doi: 10.1080/15287390306409.

[79] Venkatraman M, Konga D, Peramaiyan R, Ganapathy E, Dhanapal S. Reduction of mitochondrial oxidative damage and improved mitochondrial efficiency by administration of crocetin against benzo[a]pyrene induced experimental animals. Biol Pharm Bull 2008;31:1639-45.

[80] Lee BM, Kwack SJ, Kim HS. Age-related changes in oxidative DNA damage and benzo(a)pyrene diolepoxide-I (BPDE-I)-DNA adduct levels in human stomach. J Toxicol Environ Health A 2005;68:1599-610. doi: 10.1080/15287390500182818.

[81] Isabel RR, Sandra GA, Rafael VP, Carmen MV, Josefina CE, del Carmen CE, et al. Evaluation of 8hydroxy-2'-deoxyguanosine (8-OHdG) adduct levels and DNA strand breaks in human peripheral blood lymphocytes exposed in vitro to polycyclic aromatic hydrocarbons with or without animal metabolic activation. Toxicol Mech Methods 2012;22:170-83. doi: 10.3109/15376516.2011.623330.

[82] Genies C, Maître A, Lefèbvre E, Jullien A, Chopard-Lallier M, Douki T. The extreme variety of genotoxic response to benzo[a]pyrene in three different human cell lines from three different organs. PLoS One. 2013;8(11):e78356. doi: 10.1371/journal.pone.0078356.

[83] Park SY, Lee SM, Ye SK, Yoon SH, Chung MH, Choi J. Benzo[a]pyrene-induced DNA damage and p53 modulation in human hepatoma HepG2 cells for the identification of potential biomarkers for PAH monitoring and risk assessment. Toxicol Lett 2006;167:27-33. doi: 10.1016/j.toxlet.2006.08.011.

[84] Solhaug A, Refsnes $M$, Låg $M$, Schwarze PE, Husøy T, Holme JA. Polycyclic aromatic hydrocarbons induce both apoptotic and anti-apoptotic signals in Hepa1c1c7 cells. Carcinogenesis 2004;25:809-19. doi: 10.1093/carcin/bgh069. 
[85] Solhaug A, Refsnes M, Holme JA. Role of cell signaling involved in induction of apoptosis by benzo[a]pyrene and cyclopenta[c,d]pyrene in Hepa1c1c7 cells. J Cell Biochem 2004b;93:1143-54. doi: 10.1002/jcb.20251.

[86] Huc L, Rissel M, Solhaug A, Tekpli X, Gorria M, Torriglia A, et al. Multiple apoptotic pathways induced by p53-dependent acidification in benzo[a]pyrene-exposed hepatic F258 cells. J Cell Physiol 2006;208:527-37. doi: 10.1002/jcp.20686.

[87] Xiao H, Singh SV. p53 regulates cellular responses to environmental carcinogen benzo[a]pyrene7,8-diol-9,10-epoxide in human lung cancer cells. Cell Cycle 2007;6:1753-61. doi: 10.4161/cc.6.14.4430.

[88] Banerjee B, Chakraborty S, Ghosh D, Raha S, Sen PC, Jana K. Benzo(a)pyrene Induced p53 Mediated Male Germ Cell Apoptosis: Synergistic Protective Effects of Curcumin and Resveratrol. Front Pharmacol 2016;7:245. doi: 10.3389/fphar.2016.00245.

[89] Wani MA, Zhu Q, El-Mahdy M, Venkatachalam S, Wani AA. Enhanced sensitivity to antibenzo(a)pyrene-diol-epoxide DNA damage correlates with decreased global genomic repair attributable to abrogated p53 function in human cells. Cancer Res 2000;60:2273-80.

[90] Jiang Y, Chen X, Yang G, Wang Q, Wang J, Xiong W, et al. BaP-induced DNA damage initiated p53independent necroptosis via the mitochondrial pathway involving Bax and Bcl-2. Hum Exp Toxicol 2013;32:1245-57. doi: 10.1177/0960327113488613.

[91] Zhang W, Liu N, Wang X, Jin X, Du H, Peng G, et al. Benzo(a)pyrene-7,8-diol-9,10-epoxide induced $p 53$-independent necrosis via the mitochondria-associated pathway involving Bax and Bak activation. Hum Exp Toxicol 2015;34:179-90. doi: 10.1177/0960327114533358.

[92] Huc L, Sparfel L, Rissel M, Dimanche-Boitrel MT, Guillouzo A, Fardel O, et al. Identification of $\mathrm{Na}+\mathrm{H}+$ exchange as a new target for toxic polycyclic aromatic hydrocarbons. FASEB J. 2004;18:3446. doi: 10.1096/fj.03-0316fje.

[93] Huc L, Tekpli X, Holme JA, Rissel M, Solhaug A, Gardyn C, et al. c-Jun NH2-terminal kinase-related $\mathrm{Na}+\mathrm{H}+$ exchanger isoform 1 activation controls hexokinase II expression in benzo(a)pyrene-induced apoptosis. Cancer Res 2007;67:1696-705. doi: 10.1158/0008-5472.CAN-06-2327.

[94] Lin T, Yang MS. Benzo[a]pyrene-induced necrosis in the HepG(2) cells via PARP-1 activation and NAD(+) depletion. Toxicology 2008;245:147-53. doi: 10.1016/j.tox.2007.12.020.

[95] Jiang $Y$, Zhou X, Chen X, Yang G, Wang Q, Rao K, et al. Benzo(a)pyrene-induced mitochondrial dysfunction and cell death in p53-null Hep3B cells. Mutat Res 2011;726:75-83. doi: 10.1016/j.mrgentox.2011.08.006.

[96] Lei W, Yu R, Mandlekar S, Kong AN. Induction of apoptosis and activation of interleukin 1betaconverting enzyme/Ced-3 protease (caspase-3) and c-Jun NH2-terminal kinase 1 by benzo(a)pyrene. Cancer Res 1998;58:2102-6.

[97] Ko CB, Kim SJ, Park C, Kim BR, Shin CH, Choi S, et al. Benzo(a)pyrene-induced apoptotic death of mouse hepatoma Hepa1c1c7 cells via activation of intrinsic caspase cascade and mitochondrial dysfunction. Toxicology 2004;199:35-46. doi: 10.1016/j.tox.2004.01.039. 
[98] Holme JA, Gorria M, Arlt VM, Ovrebø S, Solhaug A, Tekpli X, et al. Different mechanisms involved in apoptosis following exposure to benzo[a]pyrene in F258 and Hepa1c1c7 cells. Chem Biol Interact 2007;167:41-55. doi: 10.1016/j.cbi.2007.01.008.

[99] Dendelé B, Tekpli X, Sergent O, Dimanche-Boitrel MT, Holme JA, Huc L, et al. Identification of the couple GSK3 $\alpha / \mathrm{c}-$ Myc as a new regulator of hexokinase II in benzo[a]pyrene-induced apoptosis. Toxicol In Vitro 2012;26:94-101. doi: 10.1016/j.tiv.2011.11.001.

[100] Chen JH, Chou FP, Lin HH, Wang CJ. Gaseous nitrogen oxide repressed benzo[a]pyrene-induced human lung fibroblast cell apoptosis via inhibiting JNK1 signals. Arch Toxicol 2005;79:694-704. doi: 10.1007/s00204-005-0001-0.

[101] Stolpmann K, Brinkmann J, Salzmann S, Genkinger D, Fritsche E, Hutzler C, et al. Activation of the aryl hydrocarbon receptor sensitises human keratinocytes for CD95L- and TRAIL-induced apoptosis. Cell Death Dis 2012;3:e388. doi: 10.1038/cddis.2012.127.

[102] Salazar I, Pavani M, Aranda W, Maya JD, Morello A, Ferreira J. Alterations of rat liver mitochondrial oxidative phosphorylation and calcium uptake by benzo[a]pyrene. Toxicol Appl Pharmacol 2004;198:1-10. doi: 10.1016/j.taap.2004.02.013.

[103] Gorria M, Huc L, Sergent O, Rebillard A, Gaboriau F, Dimanche-Boitrel MT, et al. Protective effect of monosialoganglioside GM1 against chemically induced apoptosis through targeting of mitochondrial function and iron transport. Biochem Pharmacol 2006a;72:1343-53. doi: 10.1016/j.bcp.2006.07.014.

[104] Gorria M, Tekpli X, Rissel M, Sergent O, Huc L, Landvik N, et al. A new lactoferrin- and irondependent lysosomal death pathway is induced by benzo[a]pyrene in hepatic epithelial cells. Toxicol Appl Pharmacol 2008;228:212-24. doi: 10.1016/j.taap.2007.12.021.

[105] Collin A, Hardonnière $K$, Chevanne M, Vuillemin J, Podechard N, et al. Cooperative interaction of benzo[a]pyrene and ethanol on plasma membrane remodeling is responsible for enhanced oxidative stress and cell death in primary rat hepatocytes. Free Radic Biol Med 2014;72:11-22. doi: 10.1016/j.freeradbiomed.2014.03.029.

[106] Ichim G, Tait SW. A fate worse than death: apoptosis as an oncogenic process. Nat Rev Cancer 2016;16:539-48. doi: 10.1038/nrc.2016.58.

[107] Burdick AD, Ivnitski-Steele ID, Lauer FT, Burchiel SW. PYK2 mediates anti-apoptotic AKT signaling in response to benzo[a]pyrene diol epoxide in mammary epithelial cells. Carcinogenesis 2006;27:2331-40. doi: 10.1093/carcin/bgl083.

[108] Nigam N, George J, Srivastava S, Roy P, Bhui K, Singh M, et al. Induction of apoptosis by [6]gingerol associated with the modulation of $\mathrm{p} 53$ and involvement of mitochondrial signaling pathway in B[a]P-induced mouse skin tumorigenesis. Cancer Chemother Pharmacol 2010;65:687-96. doi: 10.1007/s00280-009-1074-x.

[109] Hockley SL, Arlt VM, Brewer D, Giddings I, Phillips DH. Time- and concentration-dependent changes in gene expression induced by benzo(a)pyrene in two human cell lines, MCF-7 and HepG2. BMC Genomics 2006;7:260. doi: 10.1186/1471-2164-7-260. 
[110] Athanasoula KCh, Gogas H, Polonifi K, Vaiopoulos AG, Polyzos A, Mantzourani M. Survivin beyond physiology: orchestration of multistep carcinogenesis and therapeutic potentials. Cancer Lett 2014;347:175-82. doi: 10.1016/j.canlet.2014.02.014.

[111] Fetz V, Bier C, Habtemichael N, Schuon R, Schweitzer A, Kunkel M, et al. Inducible NO synthase confers chemoresistance in head and neck cancer by modulating survivin. Int J Cancer 2009;124:2033-41. doi: 10.1002/ijc.24182.

[112] Hardonnière K, Huc L, Podechard N, Fernier M, Tekpli X, Gallais I, et al. Benzo[a]pyrene-induced nitric oxide production acts as a survival signal targeting mitochondrial membrane potential. Toxicol In Vitro. 2015;29:1597-608. doi: 10.1016/j.tiv.2015.06.010.

[113] Sánchez-Cenizo L, Formentini L, Aldea M, Ortega AD, García-Huerta P, Sánchez-Aragó M, et al. Up-regulation of the ATPase inhibitory factor 1 (IF1) of the mitochondrial H+-ATP synthase in human tumors mediates the metabolic shift of cancer cells to a Warburg phenotype. J Biol Chem 2010;285:25308-13. doi: 10.1074/jbc.M110.146480.

[114] Heerdt BG, Houston MA, Augenlicht LH. Growth properties of colonic tumor cells are a function of the intrinsic mitochondrial membrane potential. Cancer Res 2006;66:1591-6. doi: 10.1158/00085472.CAN-05-2717.

[115] Hardonnière K, Saunier E, Lemarié A, Fernier M, Gallais I, Héliès-Toussaint C, et al. The environmental carcinogen benzo[a]pyrene induces a Warburg-like metabolic reprogramming dependent on NHE1 and associated with cell survival. Sci Rep 2016;6:30776. doi: 10.1038/srep30776.

[116] Patra KC, Hay N. The pentose phosphate pathway and cancer. Trends Biochem Sci. 2014;39:347-54. doi: 10.1016/j.tibs.2014.06.005.

[117] Payen VL, Porporato PE, Baselet B, Sonveaux P. Metabolic changes associated with tumor metastasis, part 1: tumor $\mathrm{pH}$, glycolysis and the pentose phosphate pathway. Cell Mol Life Sci 2016;73:1333-48. doi: 10.1007/s00018-015-2098-5.

[118] Nault R, Fader KA, Kirby MP, Ahmed S, Matthews J, Jones AD, et al. Pyruvate Kinase Isoform Switching and Hepatic Metabolic Reprogramming by the Environmental Contaminant 2,3,7,8Tetrachlorodibenzo-p-Dioxin. Toxicol Sci 2016;149:358-71. doi: 10.1093/toxsci/kfv245.

[119] Souza T, Jennen D, van Delft J, van Herwijnen M, Kyrtoupolos S, Kleinjans J. New insights into BaP-induced toxicity: role of major metabolites in transcriptomics and contribution to hepatocarcinogenesis. Arch Toxicol 2016;90:1449-58. doi: 10.1007/s00204-015-1572-z.

[120] Niestroy J, Barbara A, Herbst K, Rode S, van Liempt M, Roos PH. Single and concerted effects of benzo[a]pyrene and flavonoids on the AhR and Nrf2-pathway in the human colon carcinoma cell line Caco-2. Toxicol In Vitro 2011;25:671-83. doi: 10.1016/j.tiv.2011.01.008.

[121] Surya R, Héliès-Toussaint C, Martin OC, Gauthier T, Guéraud F, Taché S, et al. Red meat and colorectal cancer: Nrf2-dependent antioxidant response contributes to the resistance of preneoplastic colon cells to fecal water of hemoglobin- and beef-fed rats. Carcinogenesis 2016;37:635-45. doi: 10.1093/carcin/bgw035.

[122] Menegon S, Columbano A, Giordano S. The Dual Roles of NRF2 in Cancer. Trends Mol Med. 2016;22:578-93. doi: 10.1016/j.molmed.2016.05.002. 
[123] Chartoumpekis DV, Wakabayashi N, Kensler TW. Keap1/Nrf2 pathway in the frontiers of cancer and non-cancer cell metabolism. Biochem Soc Trans 2015;43:639-44. doi: 10.1042/BST20150049.

[124] Tekpli X, Rivedal E, Gorria M, Landvik NE, Rissel M, Dimanche-Boitrel MT, et al. The B[a]Pincreased intercellular communication via translocation of connexin-43 into gap junctions reduces apoptosis. Toxicol Appl Pharmacol 2010;242:231-40. doi: 10.1016/j.taap.2009.10.012.

[125] Trosko JE, Chang CC, Upham BL, Tai MH. Ignored hallmarks of carcinogenesis: stem cells and cell-cell communication. Ann N Y Acad Sci 2004;1028:192-201. doi: 10.1196/annals.1322.023.

[126] Bláha L, Kapplová P, Vondrácek J, Upham B, Machala M. Inhibition of gap-junctional intercellular communication by environmentally occurring polycyclic aromatic hydrocarbons. Toxicol Sci 2002;65:43-51.

[127] Topinka J, Marvanová S, Vondrácek J, Sevastyanova O, Nováková Z, Krcmár P, et al. DNA adducts formation and induction of apoptosis in rat liver epithelial 'stem-like' cells exposed to carcinogenic polycyclic aromatic hydrocarbons. Mutat Res. 2008;638:122-32. doi: 10.1016/j.mrfmmm.2007.09.004.

[128] Wei Y, Zhao L, He W, Yang J, Geng C, Chen Y, et al. Benzo[a]pyrene promotes gastric cancer cell proliferation and metastasis likely through the Aryl hydrocarbon receptor and ERK-dependent induction of MMP9 and c-myc. Int J Oncol 2016 Aug 29. doi: 10.3892/ijo.2016.3674. [Epub ahead of print]

[129] Mavrofrydi O, Mavroeidi P, Papazafiri P. Comparative assessment of HIF-1 $\alpha$ and Akt responses in human lung and skin cells exposed to benzo[ $\alpha]$ pyrene: Effect of conditioned medium from preexposed primary fibroblasts. Environ Toxicol 2016;31:1103-12. doi: 10.1002/tox.22119.

[130] Burdick AD, Davis JW 2nd, Liu KJ, Hudson LG, Shi H, Monske ML, et al. Benzo(a)pyrene quinones increase cell proliferation, generate reactive oxygen species, and transactivate the epidermal growth factor receptor in breast epithelial cells. Cancer Res 2003;63:7825-33.

[131] Plísková M, Vondrácek J, Vojtesek B, Kozubík A, Machala M. Deregulation of cell proliferation by polycyclic aromatic hydrocarbons in human breast carcinoma MCF-7 cells reflects both genotoxic and nongenotoxic events. Toxicol Sci 2005;83:246-56. doi: 10.1093/toxsci/kfi040.

[132] Kometani T, Yoshino I, Miura N, Okazaki H, Ohba T, Takenaka T, et al. Benzo[a]pyrene promotes proliferation of human lung cancer cells by accelerating the epidermal growth factor receptor signaling pathway. Cancer Lett 2009;278:27-33. doi: 10.1016/j.canlet.2008.12.017.

[133] Chramostová K, Vondrácek J, Sindlerová L, Vojtesek B, Kozubík A, Machala M. Polycyclic aromatic hydrocarbons modulate cell proliferation in rat hepatic epithelial stem-like WB-F344 cells. Toxicol Appl Pharmacol 2004;196:136-48. doi: 10.1016/j.taap.2003.12.008.

[134] Andrysík Z, Vondrácek J, Machala M, Krcmár P, Svihálková-Sindlerová L, Kranz A, Weiss C, Faust $D$, Kozubík A, Dietrich C. The aryl hydrocarbon receptor-dependent deregulation of cell cycle control induced by polycyclic aromatic hydrocarbons in rat liver epithelial cells. Mutat Res 2007;615:87-97. doi: 10.1016/j.mrfmmm.2006.10.004. 
[135] Vondráček J, Machala M. Environmental Ligands of the Aryl Hydrocarbon Receptor and Their Effects in Models of Adult Liver Progenitor Cells. Stem Cells Int 2016;2016:4326194. doi: $10.1155 / 2016 / 4326194$.

[136] Huber MA, Kraut N, Beug $\mathrm{H}$. Molecular requirements for epithelial-mesenchymal transition during tumor progression. Curr Opin Cell Biol 2005;17:548-58. doi: 10.1016/j.ceb.2005.08.001.

[137] Yoshino I, Kometani T, Shoji F, Osoegawa A, Ohba T, Kouso H, et al. Induction of epithelialmesenchymal transition-related genes by benzo[a]pyrene in lung cancer cells. Cancer 2007;110:36974. doi: 10.1002/cncr.22728.

[138] Ba Q, Li J, Huang C, Qiu H, Li J, Chu R, et al. Effects of benzo[a]pyrene exposure on human hepatocellular carcinoma cell angiogenesis, metastasis, and NF-KB signaling. Environ Health Perspect. 2015;123:246-54. doi: 10.1289/ehp.1408524.

[139] Dong R, Wang Q, He XL, Chu YK, Lu JG, Ma QJ. Role of nuclear factor kappa B and reactive oxygen species in the tumor necrosis factor-alpha-induced epithelial-mesenchymal transition of MCF-7 cells. Braz J Med Biol Res 2007;40:1071-8.

[140] Song MK, Kim YJ, Song M, Choi HS, Park YK, Ryu JC. Polycyclic aromatic hydrocarbons induce migration in human hepatocellular carcinoma cells (HepG2) through reactive oxygen speciesmediated p38 MAPK signal transduction. Cancer Sci 2011;102:1636-44. doi: 10.1111/j.13497006.2011.02000.x.

[141] Barouki R, Coumoul X. Cell migration and metastasis markers as targets of environmental pollutants and the Aryl hydrocarbon receptor. Cell Adh Migr 2010;4:72-6.

[142] Castillo-Sanchez R, Villegas-Comonfort S, Galindo-Hernandez O, Gomez R, Salazar EP. Benzo[a]-pyrene induces FAK activation and cell migration in MDA-MB-231 breast cancer cells. Cell Biol Toxicol 2013;29:303-19. doi: 10.1007/s10565-013-9254-1.

[143] Palmirotta R, Cives M, Della-Morte D, Capuani B, Lauro D, Guadagni F, et al. Sirtuins and Cancer: Role in the Epithelial-Mesenchymal Transition. Oxid Med Cell Longev 2016;2016:3031459. doi: $10.1155 / 2016 / 3031459$.

[144] Ye X, Li M, Hou T, Gao T, Zhu WG, Yang Y. Sirtuins in glucose and lipid metabolism. Oncotarget 2016 Sep 21. doi: 10.18632/oncotarget.12157. [Epub ahead of print]

[145] Lu J, Zhang M, Huang Z, Sun S, Zhang $Y$, Zhang L, et al. SIRT1 in B[a]P-induced lung tumorigenesis. Oncotarget 2015;6:27113-29. doi: 10.18632/oncotarget.4729.

[146] Bersaas A, Arnoldussen YJ, Sjøberg M, Haugen A, Mollerup S. Epithelial-mesenchymal transition and FOXA genes during tobacco smoke carcinogen induced transformation of human bronchial epithelial cells. Toxicol In Vitro 2016;35:55-65. doi: 10.1016/j.tiv.2016.04.012.

[147] Podechard N, Lecureur V, Le Ferrec E, Guenon I, Sparfel L, Gilot D, et al. Interleukin-8 induction by the environmental contaminant benzo(a)pyrene is aryl hydrocarbon receptor-dependent and leads to lung inflammation. Toxicol Lett 2008;177:130-7. doi: 10.1016/j.toxlet.2008.01.006.

[148] Shahid A, Ali R, Ali N, Hasan SK, Rashid S, Majed F, et al. Attenuation of genotoxicity, oxidative stress, apoptosis and inflammation by rutin in benzo(a)pyrene exposed lungs of mice: plausible role of NF-KB, TNF- $\alpha$ and Bcl-2. J Complement Integr Med 2016;13:17-29. doi: 10.1515/jcim-2015-0078. 
[149] Sparfel L, Pinel-Marie ML, Boize M, Koscielny S, Desmots S, Pery A, et al. Transcriptional signature of human macrophages exposed to the environmental contaminant benzo(a)pyrene. Toxicol Sci 2010;114:247-59. doi: 10.1093/toxsci/kfq007.

[150] Zaccaria KJ, McClure PR. Using immunotoxicity information to improve cancer risk assessment for polycyclic aromatic hydrocarbon mixtures. Int J Toxicol 2013;32:236-50. doi: 10.1177/1091581813492829.

[151] Huc L, Tekpli X, Rebillard A, Dimanche-Boitrel MT, Lagadic-Gossmann D. Role for NHE1 in chemically-induced apoptosis. In: Dominique Lagadic-Gossmann, editor. Proton homeostasis and cell death, Kerala: India/ Research Signpost Publisher; 2011, pp 65-81.

[152] Tekpli X, Rissel M, Huc L, Catheline D, Sergent O, Rioux V, et al. Membrane remodeling, an early event in benzo[a]pyrene-induced apoptosis. Toxicol Appl Pharmacol 2010;243:68-76. doi: 10.1016/j.taap.2009.11.014.

[153] Tekpli X, Huc L, Lacroix J, Rissel M, Poët M, Noël J, et al. Regulation of Na+/H+ exchanger 1 allosteric balance by its localization in cholesterol- and caveolin-rich membrane microdomains. J Cell Physiol. 2008;216:207-20. doi: 10.1002/jcp.21395.

[154] Tekpli X, Huc L, Sergent O, Dendelé B, Dimanche-Boitrel MT, Holme JA, et al. NHE-1 relocation outside cholesterol-rich membrane microdomains is associated with its benzo[a]pyrene-related apoptotic function. Cell Physiol Biochem 2012;29:657-66. doi: 10.1159/000171027.

[155] Cao Z, Fan-Minogue H, Bellovin DI, Yevtodiyenko A, Arzeno J, Yang Q, et al. MYC phosphorylation, activation, and tumorigenic potential in hepatocellular carcinoma are regulated by HMG-CoA reductase. Cancer Res 2011;71:2286-97. doi: 10.1158/0008-5472.CAN-10-3367.

[156] Morrish F, Isern N, Sadilek M, Jeffrey M, Hockenbery DM. c-Myc activates multiple metabolic networks to generate substrates for cell-cycle entry. Oncogene 2009;28:2485-91. doi: 10.1038/onc.2009.112.

[157] Hsieh AL, Walton ZE, Altman BJ, Stine ZE, Dang CV. MYC and metabolism on the path to cancer. Semin Cell Dev Biol 2015;43:11-21. doi: 10.1016/j.semcdb.2015.08.003.

[158] Majewski N, Nogueira V, Robey RB, Hay N. Akt inhibits apoptosis downstream of BID cleavage via a glucose-dependent mechanism involving mitochondrial hexokinases. Mol Cell Biol 2004;24:73040.

[159] Kotliarova S, Pastorino S, Kovell LC, Kotliarov Y, Song H, Zhang W, et al. Glycogen synthase kinase-3 inhibition induces glioma cell death through c-MYC, nuclear factor-kappaB, and glucose regulation. Cancer Res 2008;68:6643-51. doi: 10.1158/0008-5472.CAN-08-0850.

[160] Baumgartner $\mathrm{M}$, Patel $\mathrm{H}$, Barber DL. $\mathrm{Na}(+) / H(+)$ exchanger NHE1 as plasma membrane scaffold in the assembly of signaling complexes. Am J Physiol Cell Physiol 2004;287:C844-50. doi: 10.1152/ajpcell.00094.2004.

[161] Wu KL, Khan S, Lakhe-Reddy S, Jarad G, Mukherjee A, Obejero-Paz CA, et al. The NHE1 Na+/H+ exchanger recruits ezrin/radixin/moesin proteins to regulate Akt-dependent cell survival. J Biol Chem 2004;279:26280-6. doi: 10.1074/jbc.M400814200. 
[162] Mitsiades CS, Mitsiades N, Koutsilieris M. The Akt pathway: molecular targets for anti-cancer drug development. Curr Cancer Drug Targets 2004;4:235-56.

[163] Peixoto EB, Papadimitriou A, Teixeira DA, Montemurro C, Duarte DA, Silva KC, et al. Reduced LRP6 expression and increase in the interaction of GSK3 $\beta$ with p53 contribute to podocyte apoptosis in diabetes mellitus and are prevented by green tea. J Nutr Biochem 2015;26:416-30. doi: 10.1016/j.jnutbio.2014.11.012.

[164] Altairac S, Zeggai S, Perani P, Courtois $\mathrm{Y}$, Torriglia A. Apoptosis induced by $\mathrm{Na}+/ \mathrm{H}+$ antiport inhibition activates the LEI/L-DNase II pathway. Cell Death Differ 2003;10:548-57. doi: 10.1038/sj.cdd.4401195.

[165] Gorria M, Tekpli X, Sergent O, Huc L, Gaboriau F, Rissel M, et al. Membrane fluidity changes are associated with benzo[a]pyrene-induced apoptosis in F258 cells: protection by exogenous cholesterol. Ann N Y Acad Sci 2006b;1090:108-12. doi: 10.1196/annals.1378.011.

[166] Lacroix J, Poët M, Huc L, Morello V, Djerbi N, Ragno M, et al. Kinetic analysis of the regulation of the $\mathrm{Na}+\mathrm{H}+$ exchanger NHE-1 by osmotic shocks. Biochemistry 2008;47:13674-85. doi: $10.1021 /$ bi801368n.

[167] Meima ME, Mackley JR, Barber DL. Beyond ion translocation: structural functions of the sodium-hydrogen exchanger isoform-1. Curr Opin Nephrol Hypertens 2007;16:365-72. doi: 10.1097/MNH.0b013e3281bd888d.

[168] Astarie C, Le Quan Sang KH, David-Dufilho M, Devynck MA. Further investigation of platelet cytosolic alkalinization in essential hypertension. J Hypertens 1992;10:849-54.

[169] Denker SP, Huang DC, Orlowski J, Furthmayr H, Barber DL. Direct binding of the Na-H exchanger NHE1 to ERM proteins regulates the cortical cytoskeleton and cell shape independently of $\mathrm{H}(+)$ translocation. Mol Cell 2000;6:1425-36.

[170] Lemarié A, Huc L, Pazarentzos E, Mahul-Mellier AL, Grimm S. Specific disintegration of complex II succinate:ubiquinone oxidoreductase links $\mathrm{pH}$ changes to oxidative stress for apoptosis induction. Cell Death Differ 2011;18:338-49. doi: 10.1038/cdd.2010.93.

[171] Kalkhof S, Dautel F, Loguercio S, Baumann S, Trump S, Jungnickel H, et al. Pathway and timeresolved benzo[a]pyrene toxicity on Hepa1c1c7 cells at toxic and subtoxic exposure. J Proteome Res 2015;14:164-82. doi: 10.1021/pr500957t.

[172] Reshkin SJ, Bellizzi A, Caldeira S, Albarani V, Malanchi I, Poignee M, et al. Na+/H+ exchangerdependent intracellular alkalinization is an early event in malignant transformation and plays an essential role in the development of subsequent transformation-associated phenotypes. FASEB J 2000;14:2185-97. doi: 10.1096/fj.00-0029com.

[173] Gatenby RA, Gillies RJ. A microenvironmental model of carcinogenesis. Nat Rev Cancer 2008;8:56-61. doi: 10.1038/nrc2255.

[174] Sharma M, Astekar M, Soi S, Manjunatha BS, Shetty DC, Radhakrishnan R. pH Gradient Reversal: An Emerging Hallmark of Cancers. Recent Pat Anticancer Drug Discov 2015;10:244-58. 
[175] Gao Z, Bu Y, Liu X, Wang X, Zhang G, Wang E, et al. TCDD promoted EMT of hFPECs via AhR, which involved the activation of EGFR/ERK signaling. Toxicol Appl Pharmacol 2016;298:48-55. doi: 10.1016/j.taap.2016.03.005.

[176] Reyes-Reyes EM, Ramos IN, Tavera-Garcia MA, Ramos KS. The aryl hydrocarbon receptor agonist benzo(a)pyrene reactivates LINE-1 in HepG2 cells through canonical TGF- $\beta 1$ signaling: implications in hepatocellular carcinogenesis. Am J Cancer Res 2016;6:1066-77.

[177] Peak M, al-Habori M, Agius L. Regulation of glycogen synthesis and glycolysis by insulin, $\mathrm{pH}$ and cell volume. Interactions between swelling and alkalinization in mediating the effects of insulin. Biochem J 1992;282:797-805.

[178] Putney LK, Barber DL. Expression profile of genes regulated by activity of the $\mathrm{Na}-\mathrm{H}$ exchanger NHE1. BMC Genomics 2004;5:46. doi: 10.1186/1471-2164-5-46.

[179] Calderon-Montano JM, Burgos-Moron E, Perez-Guerrero C, Salvador J, Robles A, Lopez-Lazaro $\mathrm{M}$. Role of the intracellular $\mathrm{pH}$ in the metabolic switch between oxidative phosphorylation and aerobic glycolysis - Relevance to cancer. WebMedCentral Cancer 2011; 2(3): WMC001716.

[180] Quach CH, Jung KH, Lee JH, Park JW, Moon SH, Cho YS, et al. Mild Alkalization Acutely Triggers the Warburg Effect by Enhancing Hexokinase Activity via Voltage-Dependent Anion Channel Binding. PLoS One 2016;11(8):e0159529. doi: 10.1371/journal.pone.0159529.

[181] Miccoli L, Oudard S, Sureau F, Poirson F, Dutrillaux B, Poupon MF. Intracellular pH governs the subcellular d istribution of hexokinase in a glioma cell line. Biochem J 1996;313:957-62.

[182] Mathupala SP, Ko YH, Pedersen PL. Hexokinase-2 bound to mitochondria: cancer's stygian link to the "Warburg Effect" and a pivotal target for effective therapy. Semin Cancer Biol 2009;19:17-24. doi: 10.1016/j.semcancer.2008.11.006.

[183] Rády P, Arany I, Boján F, Kertai P. Effect of carcinogenic and non-carcinogenic chemicals on the activities of four glycolytic enzymes in mouse lung. Chem Biol Interact 1980;31:209-13.

[184] Mraiche F, Wagg CS, Lopaschuk GD, Fliegel L. Elevated levels of activated NHE1 protect the myocardium and improve metabolism following ischemia/reperfusion injury. J Mol Cell Cardiol 2011;50:157-64. doi: 10.1016/j.yjmcc.2010.10.016.

[185] Grimm S. Respiratory chain complex II as general sensor for apoptosis. Biochim Biophys Acta 2013;1827:565-72. doi: 10.1016/j.bbabio.2012.09.009.

[186] Hwang MS, Rohlena J, Dong LF, Neuzil J, Grimm S. Powerhouse down: Complex II dissociation in the respiratory chain. Mitochondrion 2014;19 Pt A:20-8. doi: 10.1016/j.mito.2014.06.001.

[187] Tretter L, Patocs A, Chinopoulos C. Succinate, an intermediate in metabolism, signal transduction, ROS, hypoxia, and tumorigenesis. Biochim Biophys Acta 2016;1857:1086-101. doi: 10.1016/j.bbabio.2016.03.012.

[188] Santo-Domingo J, Demaurex N. Perspectives on: SGP symposium on mitochondrial physiology and medicine: the renaissance of mitochondrial pH. J Gen Physiol 2012;139:415-23. doi: $10.1085 /$ jgp.201110767. 
[189] Lambert AJ, Brand MD. Superoxide production by NADH:ubiquinone oxidoreductase (complex I) depends on the pH gradient across the mitochondrial inner membrane. Biochem J 2004;382:511-7. doi: 10.1042/BJ20040485.

[190] Garciarena CD, Caldiz Cl, Correa MV, Schinella GR, Mosca SM, Chiappe de Cingolani GE, et al. $\mathrm{Na}+/ \mathrm{H}+$ exchanger-1 inhibitors decrease myocardial superoxide production via direct mitochondrial action. J Appl Physiol 2008;105:1706-13. doi: 10.1152/japplphysiol.90616.2008.

[191] Villa-Abrille MC, Cingolani E, Cingolani HE, Alvarez BV. Silencing of cardiac mitochondrial NHE1 prevents mitochondrial permeability transition pore opening. Am J Physiol Heart Circ Physiol 2011;300:H1237-51. doi: 10.1152/ajpheart.00840.2010.

[192] Alvarez BV, Villa-Abrille MC. Mitochondrial NHE1: a newly identified target to prevent heart disease. Front Physiol 2013;4:152. doi: 10.3389/fphys.2013.00152.

[193] Morita T, Nagaki T, Fukuda I, Okumura K. Clastogenicity of low pH to various cultured mammalian cells. Mutat Res. 1992;268:297-305.

[194] Yuan J, Narayanan L, Rockwell S, Glazer PM. Diminished DNA repair and elevated mutagenesis in mammalian cells exposed to hypoxia and low pH. Cancer Res 2000;60:4372-6.

[195] Dimanche-Boitrel MT, Meurette O, Jouan-Lanhouët S, Rebillard A, Huc L, Lagadic-Gossmann D. The acidic extracellular $\mathrm{pH}$ : Origin, role in tumorigenesis and cancer therapy. In: Dominique LagadicGossmann, editor. Proton homeostasis and cell death, Kerala: India/ Research Signpost Publisher; 2011, pp 105-118.

[196] Andersen AP, Moreira JM, Pedersen SF. Interactions of ion transporters and channels with cancer cell metabolism and the tumour microenvironment. Philos Trans R Soc Lond B Biol Sci 2014;369:20130098. doi: 10.1098/rstb.2013.0098.

[197] Schelling JR, Abu Jawdeh BG. Regulation of cell survival by Na+/H+ exchanger-1. Am J Physiol Renal Physiol 2008;295:F625-32. doi: 10.1152/ajprenal.90212.2008.

[198] Mukhin YV, Garnovskaya MN, Ullian ME, Raymond JR. ERK is regulated by sodium-proton exchanger in rat aortic vascular smooth muscle cells. J Biol Chem 2004;279:1845-52. doi: 10.1074/jbc.M304907200.

[199] Pedersen SF, Darborg BV, Rentsch ML, Rasmussen M. Regulation of mitogen-activated protein kinase pathways by the plasma membrane $\mathrm{Na}+\mathrm{H}+$ exchanger, NHE1. Arch Biochem Biophys 2007;462:195-201. doi: 10.1016/j.abb.2006.12.001.

[200] Stock C, Schwab A. Protons make tumor cells move like clockwork. Pflügers Arch. 2009;458:981-92. doi: 10.1007/s00424-009-0677-8.

[201] Denker SP, Barber DL. Cell migration requires both ion translocation and cytoskeletal anchoring by the Na-H exchanger NHE1. J Cell Biol 2002;159:1087-96. doi: 10.1083/jcb.200208050.

[202] Ludwig FT, Schwab A, Stock C. The $\mathrm{Na}+/ \mathrm{H}+$-exchanger (NHE1) generates $\mathrm{pH}$ nanodomains at focal adhesions. J Cell Physiol. 2013;228:1351-8. doi: 10.1002/jcp.24293.

[203] Chiang Y, Chou CY, Hsu KF, Huang YF, Shen MR. EGF upregulates $\mathrm{Na}+\mathrm{H}+$ exchanger NHE1 by post-translational regulation that is important for cervical cancer cell invasiveness. J Cell Physiol 2008;214:810-9. doi: 10.1002/jcp.21277. 
[204] Brisson L, Driffort V, Benoist L, Poet M, Counillon L, Antelmi E, et al. NaV1.5 $\mathrm{Na}^{+}$channels allosterically regulate the NHE-1 exchanger and promote the activity of breast cancer cell invadopodia. J Cell Sci 2013;126:4835-42. doi: 10.1242/jcs.123901.

[205] Antelmi E, Cardone RA, Greco MR, Rubino R, Di Sole F, Martino NA, et al. B1 integrin binding phosphorylates ezrin at T567 to activate a lipid raft signalsome driving invadopodia activity and invasion. PLoS One 2013;8:e75113. doi: 10.1371/journal.pone.0075113.

[206] Lin Y, Chang G, Wang J, Jin W, Wang L, Li H, et al. NHE1 mediates MDA-MB-231 cells invasion through the regulation of MT1-MMP. Exp Cell Res 2011;317:2031-40. doi: 10.1016/j.yexcr.2011.05.026.

[207] Lin Y, Wang J, Jin W, Wang L, Li H, Ma L, et al. NHE1 mediates migration and invasion of HeLa cells via regulating the expression and localization of MT1-MMP. Cell Biochem Funct 2012;30:41-6. doi: 10.1002/cbf.1815.

[208] Nguyen TN, Wang HJ, Zalzal S, Nanci A, Nabi IR. Purification and characterization of beta-actinrich tumor cell pseudopodia: role of glycolysis. Exp Cell Res 2000;258:171-83. doi: 10.1006/excr.2000.4929.

[209] Attanasio F, Caldieri G, Giacchetti G, van Horssen R, Wieringa B, Buccione R. Novel invadopodia components revealed by differential proteomic analysis. Eur J Cell Biol 2011;90:115-27. doi: 10.1016/j.ejcb.2010.05.004.

[210] Mo XG, Chen QW, Li XS, Zheng MM, Ke DZ, Deng W, et al. Suppression of NHE1 by small interfering RNA inhibits HIF-1 $\alpha$-induced angiogenesis in vitro via modulation of calpain activity. Microvasc Res. 2011;81:160-8. doi: 10.1016/j.mvr.2010.12.004.

[211] Németh ZH, Deitch EA, Szabó C, Mabley JG, Pacher P, Fekete Z, et al. Na+/H+ exchanger blockade inhibits enterocyte inflammatory response and protects against colitis. Am J Physiol Gastrointest Liver Physiol 2002;283:G122-32. doi: 10.1152/ajpgi.00015.2002.

[212] Yang X, Bai H, Cai W, Liu J, Wang Y, Xu Y, et al. Inhibition of $\mathrm{Na}+\mathrm{H}+$ exchanger 1 by cariporide alleviates burn-induced multiple organ injury. J Surg Res 2013;185:797-804. doi: 10.1016/j.jss.2013.06.049.

[213] Harguindey S, Arranz JL, Polo Orozco JD, Rauch C, Fais S, Cardone RA, et al. Cariporide and other new and powerful NHE1 inhibitors as potentially selective anticancer drugs--an integral molecular/biochemical/metabolic/clinical approach after one hundred years of cancer research. J Transl Med 2013;11:282. doi: 10.1186/1479-5876-11-282.

[214] Putney LK, Denker SP, Barber DL. The changing face of the Na+/H+ exchanger, NHE1: structure, regulation, and cellular actions. Annu Rev Pharmacol Toxicol 2002;42:527-52. doi: 10.1146/annurev.pharmtox.42.092001.143801.

[215] Petrecca K, Atanasiu R, Grinstein S, Orlowski J, Shrier A. Subcellular localization of the $\mathrm{Na}+/ \mathrm{H}+$ exchanger NHE1 in rat myocardium. Am J Physiol 1999;276:H709-17.

[216] Peracchia C. Chemical gating of gap junction channels; roles of calcium, $\mathrm{pH}$ and calmodulin. Biochim Biophys Acta. 2004;1662:61-80. doi: 10.1016/j.bbamem.2003.10.020. 
[217] Swietach P, Rossini A, Spitzer KW, Vaughan-Jones RD. H+ ion activation and inactivation of the ventricular gap junction: a basis for spatial regulation of intracellular pH. Circ Res 2007;100:1045-54. doi: 10.1161/01.RES.0000264071.11619.47.

[218] Nandakumar N, Rengarajan T, Balamurugan A, Balasubramanian MP. Modulating effects of hesperidin on key carbohydrate-metabolizing enzymes, lipid profile, and membrane-bound adenosine triphosphatases against 7,12-dimethylbenz(a)anthracene-induced breast carcinogenesis. Hum Exp Toxicol 2014;33:504-16. doi: 10.1177/0960327113485252.

[219] Tekpli X, Holme JA, Sergent O, Lagadic-Gossmann D. Importance of plasma membrane dynamics in chemical-induced carcinogenesis. Recent Pat Anticancer Drug Discov 2011;6:347-53. doi: $10.2174 / 157489211796957784$.

[220] Tekpli X, Holme JA, Sergent O, Lagadic-Gossmann D. Role for membrane remodeling in cell death: implication for health and disease. Toxicology 2013;304:141-57. doi: 10.1016/j.tox.2012.12.014.

[221] Aravena C, Beltrán AR, Cornejo M, Torres V, Díaz ES, Guzmán-Gutiérrez E, et al. Potential role of sodium-proton exchangers in the low concentration arsenic trioxide-increased intracellular $\mathrm{pH}$ and cell proliferation. PLoS One 2012;7:e51451. doi: 10.1371/journal.pone.0051451.

[222] Wang X, Mu X, Zhang J, Huang Q, Alamdar A, Tian M, et al. Serum metabolomics reveals that arsenic exposure disrupted lipid and amino acid metabolism in rats: a step forward in understanding chronic arsenic toxicity. Metallomics 20157:544-52. doi: 10.1039/c5mt00002e.

[223] Zhao F, Severson P, Pacheco S, Futscher BW, Klimecki WT. Arsenic exposure induces the Warburg effect in cultured human cells. Toxicol Appl Pharmacol 2013;271:72-7. doi: 10.1016/j.taap.2013.04.020.

[224] Chen H, Lee LS, Li G, Tsao SW, Chiu JF. Upregulation of glycolysis and oxidative phosphorylation in benzo[ $\alpha]$ pyrene and arsenic-induced rat lung epithelial transformed cells. Oncotarget 2016 Jun 3. doi: 10.18632/oncotarget.9814. [Epub ahead of print]

[225] Huc L, Gilot D, Gardyn C, Rissel M, Dimanche-Boitrel MT, Guillouzo A, et al. Apoptotic mitochondrial dysfunction induced by benzo(a)pyrene in liver epithelial cells: role of p53 and pHi changes. Ann N Y Acad Sci 2003;1010:167-70.

[226] Kruiswijk F, Labuschagne CF, Vousden KH. p53 in survival, death and metabolic health: a lifeguard with a licence to kill. Nat Rev Mol Cell Biol 2015;16:393-405. doi: 10.1038/nrm4007.

[227] Aylon Y, Oren M. The Paradox of p53: What, How, and Why? Cold Spring Harb Perspect Med. 2016;6(10). pii: a026328. doi: 10.1101/cshperspect.a026328.

[228] Schwartzenberg-Bar-Yoseph F, Armoni M, Karnieli E. The tumor suppressor p53 down-regulates glucose transporters GLUT1 and GLUT4 gene expression. Cancer Res 2004;64:2627-33.

[229] Bensaad K, Tsuruta A, Selak MA, Vidal MN, Nakano K, Bartrons R, et al. TIGAR, a p53-inducible regulator of glycolysis and apoptosis. Cell 2006;126:107-20. doi: 10.1016/j.cell.2006.05.036.

[230] Hu W, Zhang C, Wu R, Sun Y, Levine A, Feng Z. Glutaminase 2, a novel p53 target gene regulating energy metabolism and antioxidant function. Proc Natl Acad Sci U S A 2010;107:7455-60. doi: $10.1073 /$ pnas.1001006107. 
[231] Matoba S, Kang JG, Patino WD, Wragg A, Boehm M, Gavrilova O, et al. p53 regulates mitochondrial respiration. Science 2006;312:1650-3. doi: 10.1126/science.1126863.

[232] Bergeaud M, Mathieu L, Guillaume A, Moll UM, Mignotte B, Le Floch N, et al. Mitochondrial p53 mediates a transcription-independent regulation of cell respiration and interacts with the mitochondrial F FO-ATP synthase. Cell Cycle 2013;12:2781-93. doi: 10.4161/cc.25870.

[233] Kochhar A, Kopelovich L, Sue E, Guttenplan JB, Herbert BS, Dannenberg AJ, et al. p53 modulates Hsp90 ATPase activity and regulates aryl hydrocarbon receptor signaling. Cancer Prev Res (Phila) 2014;7:596-606. doi: 10.1158/1940-6207.CAPR-14-0051.

[234] Galluzzi L, Morselli E, Kepp O, Vitale I, Pinti M, Kroemer G. Mitochondrial liaisons of p53. Antioxid Redox Signal 2011;15:1691-714. doi: 10.1089/ars.2010.3504.

[235] Zhang C, Liu J, Liang Y, Wu R, Zhao Y, Hong X, et al. Tumour-associated mutant p53 drives the Warburg effect. Nat Commun 2013;4:2935. doi: 10.1038/ncomms3935.

[236] Dendelé B, Tekpli X, Hardonnière K, Holme JA, Debure L, Catheline D, et al. Protective action of n-3 fatty acids on benzo[a]pyrene-induced apoptosis through the plasma membrane remodelingdependent NHE1 pathway. Chem Biol Interact 2014;207:41-51. doi: 10.1016/j.cbi.2013.11.002. 


\section{Figure legends}

Figure 1. Metabolic reprogramming following $B[a] P$ exposure involves the p53 pathway. (A) In order to test the role of p53 in the glycolytic shift, F258 rat hepatic epithelial cells were pre-treated for $1 \mathrm{~h}$ with pifithrin- $\alpha$ (PFT) $(10 \mu \mathrm{M})$ prior to co-exposure with $\mathrm{B}[\mathrm{a}] \mathrm{P}(50 \mathrm{nM}, 48 \mathrm{~h}$ ). Following treatments, extracellular lactate release was monitored, as previously described [114]. (B) Western blotting analysis was performed to control the sip53 inhibitory efficiency on p53 protein level as compared to the Non Targeting siRNA (siNT). HSC70 was used as a loading control. (C) Effects of p53 silencing using siRNA on the extracellular lactate release from B[a]P (50 nM, 48 h)-treated F258 cells. SiNT: non targeting SiRNA; Sip53: p53 targeting siRNA. There were at least 3 to 4 independent experiments for all conditions. ${ }^{*} \mathrm{p}<0.05 ;{ }^{* *}<0.01 ;{ }^{* * *}<0.001$ : DMSO vs $\mathrm{B}[\mathrm{a}] \mathrm{P}$-treated cells, unless otherwise quoted.

Figure 1

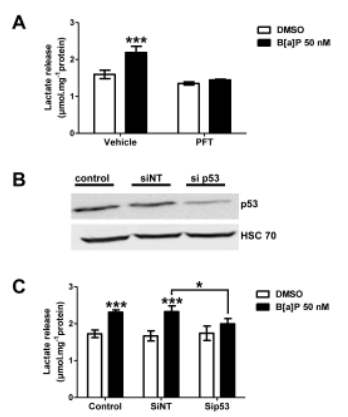


Figure 2. Effects of NHE1 inhibition on the B[a]P-elicited epithelial-to-mesenchymal transition (EMT), cell spreading and migration. To further investigate the role of NHE1 in the B[a]P-induced cell phenotype modifications, F258 rat hepatic epithelial cells were pre-treated or not for $1 \mathrm{~h}$ with cariporide $(10 \mu \mathrm{M})$ prior to co-exposure with $\mathrm{B}[\mathrm{a}] \mathrm{P}(50 \mathrm{nM}$ and $1 \mu \mathrm{M}, 48 \mathrm{~h})$. (A) Vimentin protein levels were analysed by western blotting and by fluorescence microscopy. For western blotting, HSC70 was used as a loading control. (B) Cell attachment and spreading were analysed by monitoring impedance of the cell monolayer with xCELLigence technology, as previously described [114]. The histogram plots the slope of cell index measured in F258 cells in presence or absence of cariporide $(10 \mu \mathrm{M})$, treated or not with $\mathrm{B}[\mathrm{a}] \mathrm{P}(50 \mathrm{nM})$. (C) Cell migration assays were monitored using xCELLigence technology on $\mathrm{B}[\mathrm{a}] \mathrm{P}(50 \mathrm{nM})$-treated cells, as previously described [114]. The histogram shows the effect of $\mathrm{B}[\mathrm{a}] \mathrm{P}$ on the calculated cell index normalized relative to corresponding control, in F258 cells in presence or not of cariporide $(10 \mu \mathrm{M})$. There were 3 independent experiments for all conditions. ${ }^{*} \mathrm{p}<0.05 ;{ }^{* *}<0.01 ;{ }^{* * *}<0.001: \mathrm{B}[\mathrm{a}] \mathrm{P}$-treated cells + cariporide $v s \mathrm{~B}[\mathrm{a}] \mathrm{P}$-treated cells.

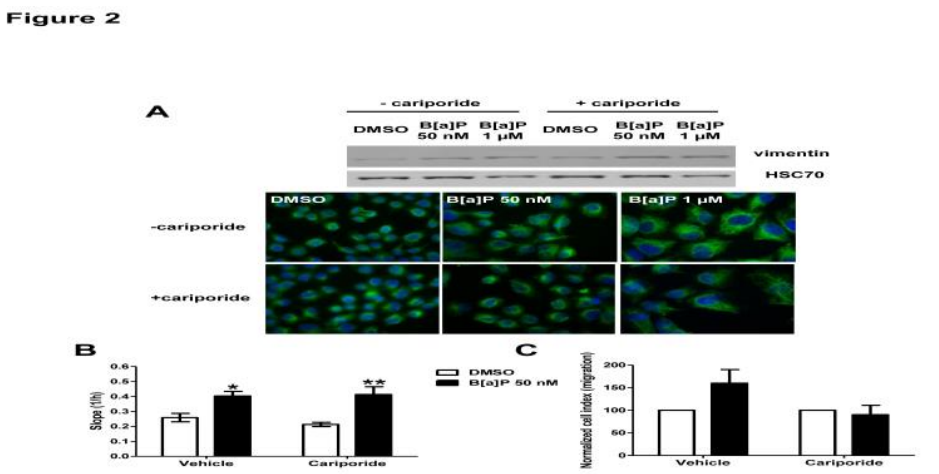


Figure 3. Schematic diagram illustrating the contribution of NHE1 activation to the B[a]P-induced glycolytic reprogramming in rat hepatic epithelial cell line F258. Upon B[a]P exposure, a shift from OXPHOS to glycolysis is induced. Alterations in OXPHOS and TCA cycle might rely upon acidification of matrix $\mathrm{pH}(\mathrm{pHm})$. The involvement of a mitochondrial isoform of NHE1 (mNHE1) in pHm acidification might be considered. Stimulation of glycolysis which results in lactate production and extracellular $\mathrm{pH}(\mathrm{pHe})$ acidification, is dependent on NHE1 activation as reflected by an increased intracellular $\mathrm{pH}$ (pHi). A role for AhR has also been detected with regard to glycolysis that might go through the NHE1 activation resulting from $\mathrm{AhR}$ and $\mathrm{H}_{2} \mathrm{O}_{2}$-dependent membrane remodeling that involves a decrease in HMGCoA reductase expression. Other roles for AhR might be expected, notably at the mitochondrial level. A nitric oxide (NO) production also triggers mitochondrial dysfunction leading to membrane hyperpolarization, and might act as a compensatory response to counteract $\Delta \mathrm{pH}$ alterations following carcinogen exposure [111]. Interestingly, p53 is also orchestrating the B[a]P-mediated metabolic response, being involved in both glycolysis enhancement and iNOS induction. However, the modalities of NHE1/AhR/p53 interplay remain to decipher. In total, the B[a]P-induced glycolytic shift appears to greatly influence cell fate decision, triggering cell survival. AhR: Aryl hydrocarbon receptor; CYP: Cytochrome P450; iNOS: inducible nitric oxide synthase; mAhR: mitochondrial AhR; mNHE1: mitochondrial NHE1; TCA cycle: tricarboxylic acid cycle; $\triangle 4 m$ : mitochondrial membrane potential.

Figure 3

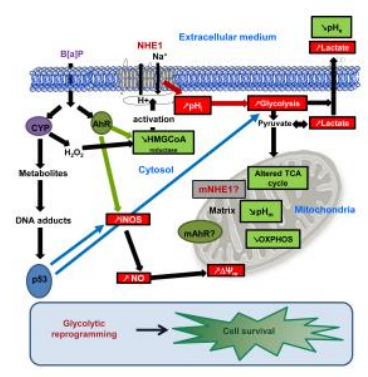


Figure 4. The cancer hallmarks shared by both NHE1 activation and B[a]P exposure. Based upon the literature, it clearly appears that several cancer hallmarks are targeted by both $\mathrm{B}[\mathrm{a}] \mathrm{P}$ exposure and NHE1 activation. Although it is known that $\mathrm{B}[\mathrm{a}] \mathrm{P}$ can promote inflammatory processes, poor evidence exists regarding NHE1 $[207,208]$. NHE1 activation has been shown to play a role in some of the hallmarks elicited by $\mathrm{B}[\mathrm{a}] \mathrm{P}$ exposure (underlined font); however, a role for this transporter will have to be tested with regards to the other hallmarks triggered by $\mathrm{B}[\mathrm{a}] \mathrm{P}$.

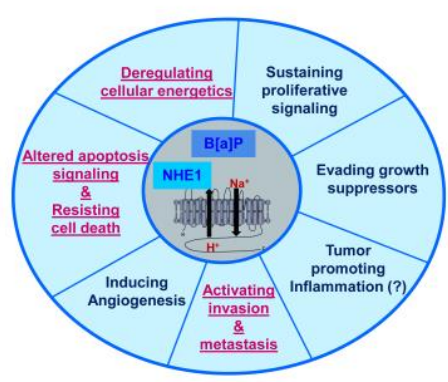

